\title{
隠岐島後における末期中新世，隠岐アルカリ 火山岩類の地質とマグマ供給系
}

\author{
Magma plumbing systems of the Latest Miocene Oki Alkaline \\ Volcanic Group, Oki-Dogo Island, SW Japan, based \\ on geology and petrology
}

\author{
小林 伸治 (Shinji KOBAYASHI)* \\ 沢田 順弘 (Yoshihiro SAWADA)** \\ 吉田 武義 (Takeyoshi YoshIDA)*
}

\begin{abstract}
A huge volume of lavas and pyroclastic rocks were erupted in Oki-Dogo island in the latest Miocene. They compose the Oki Alkaline Volcanic Group, the Hei Trachyte Group, the Tsuzurao Volcanic Group and the Tokage Trachyte Group. We examine the geology, petrography and geochemistry mainly for the Oki Alkaline Group, and present a magma plumbing story in the latest Miocene age.

The rocks from the Oki Alkaline Volcanic Group are shoshonite, trachyandesite, trachyte and rhyolite, based on their chemical composition and stratigraphy. The trachytes are divided into Trachyte- $1(\mathrm{Nb} 35-50 \mathrm{ppm})$ and $-2(\mathrm{Nb} 49-75 \mathrm{ppm})$, and the rhyolites are divided into Lower Rhyolites (Moderate- $\mathrm{SiO}_{2}$ : 71.4-73.6 wt\%), Middle Rhyolites (High- $\mathrm{SiO}_{2}$ : 74.7-75.7 wt\%), and Upper Rhyolites ( $\mathrm{Low}_{-} \mathrm{SiO}_{2}: 70.7-71.6 \mathrm{wt} \%$ ). Lower Rhyolites, Trachyte-1 were formed at the early volcanic stage. Middle Rhyolites, Trachyte- 1 were formed at the middle stage, and Upper Rhyolites, Trachytes -1 and -2 , trachyandesite and shoshonite were formed at the later stage. Rhyolitic lava domes with different compositions and feeder dikes of trachyte corresponding to individual volcanic vents occur at a number of places. This may indicate that the eruptions took place from several different vents aligned along a circular fracture.

Lower Rhyolites were derived from the lower crust, and Middle Rhyolites were derived from middle crust by partial melting processes. While, Upper Rhyolites, Trachyte- 2 and trachyandesite were generated by fractional crystallization from shoshonite magma. The heat source triggered melting of the crusts is inferred to be latent heat of crystallization in the mafic magma. These rhyolite to shoshonite magmas could have ascended through the ring fractures formed by the doming event, and have consolidated as the rocks composing the Oki Alkaline Volcanic Group. After the formation of this group, Cauldron collapse, and it is followed by the eruption of the Hei Trachyte Group and the Tsuzurao Volcanic Group. In the early Pliocene, The tectonic environment of the crust changed from a compressive to an extensional stress field. Then the eruption of the Omine Group and the Tokage Trachyte Group took place.
\end{abstract}

Keywords: Geology, Stratigraphy, The Oki Alkaline Volcanic Group, Tectonic event, Magmatic evolution, Miocene, Oki-Dogo

(平成 13 年 8 月 6 日受付, 平成 14 年 3 月 18 日受理)

*東北大学大学院理学研究科地学専攻地球物質科学, $=980-8578$ 仙台市青葉区荒巻字青葉

**島根大学総合理工学部地球資源環境学教室, 干 690-8504 松江市西川津町 1060

*Institute of Mineralogy, Petrology and Economic Geology, Graduate School of Science, Tohoku University, Aoba, Sendai 980-8578, Japan

**Department of Geoscience, Faculty of Science and Engineering, Shimane University, 1060 Nishikawatsu-cho, Matsue 6908504, Japan 


\section{I. はじめに}

島根県沖約 $60 \mathrm{~km}$ の日本海に位置する隐岐島忌 (以後 島後と呼ぶ) は隠岐群島中最大で, 直径約 17〜 $18 \mathrm{~km}$ のほ ぼ円形の島である。島後の地質については山上 (1895) や 冨田 (1927～1932) 以来古くから多くの報告があり，その 特徵として，島の半分以上を覆う多量のアルカリ火山岩類 の存在があげられている (Fig. 1)。特に末期中新世には多 様なアルカリ火山岩類が活動しており，これらは隠岐アル カリ火山岩類, 平粗面岩類, 葛尾火山岩類, トカゲ岩粗面 岩に分けられている (Uchimizu, 1966; 小林・沢田, 1998; 沢 田ら，1999)。それらの K-Ar 年代は, 隠岐アルカリ火山岩 類の全岩年代が 5.5 5.4 Ma (Uto et al., 1994), 葛尾火山 岩類に属する粗面岩中のサニディンによる年代が $5.45 \pm$ $0.17 \mathrm{Ma}$ (沢田ら，未発表データ) であり，また 5.4〜 $5.7 \mathrm{Ma}$ の全岩年代を示すショショナイト (藤巻ら， 1989; ミュジ アライトと記載) も分布する (Fig. 2A)。これらのことか ら，5～6 Ma 頃は多様なアルカリ火山岩類が広く活動して いた時期であったといえる。これらの火山岩について多く の岩石学的研究がなされているが, 隠岐アルカリ火山岩類 についての詳しい地質学的研究は少ない。また, 石田 (1985) が島後西部地域において定義した油井層が, 山崎
(1998) により郡累層と隠岐粗面岩一流紋岩類 (隠岐アル カリ火山岩類) の一部として再定義されるなど, まだ解決 すべき問題が残されている。

小林・沢田 (1998) は島後北西部に分布する隠岐アルカ リ火山岩類についての詳細な地質学的データと全岩および ガラスの化学組成に基づき, 隠岐アルカリ火山岩類の主要 なメンバーである流紋岩類には起源の異なる 2 種類が存在 することを明らかにした。本論文では，隠岐アルカリ火山 岩類についてのマグマ成因論や，そのダイナミックスを明 らかにするために, 全島的な地質調査を行い, 特に火山層 序学, 火山構造, 火道の位置などを検討する。また岩石記 載, 構成鉱物の化学組成, 全岩およびガラスの組成から, マ グマの多様性についても明らかにする。それらに基づき， 島後において最も火山活動が活発に起こった末期中新世火 山活動の全容を明らかにし，それらの成因，マグマ相互の 関係，ダイナミックスについて論じる。

\section{II. 地 質}

\section{1. 地質概略}

島後の地質は, 島後北東部に分布するドーム状の片状構 造を示す (葛尾山ドーム) 先第三紀の隠岐片麻岩類と「陸 弧ステージ」(26〜23 Ma) のカルクアルカリ火山岩類から

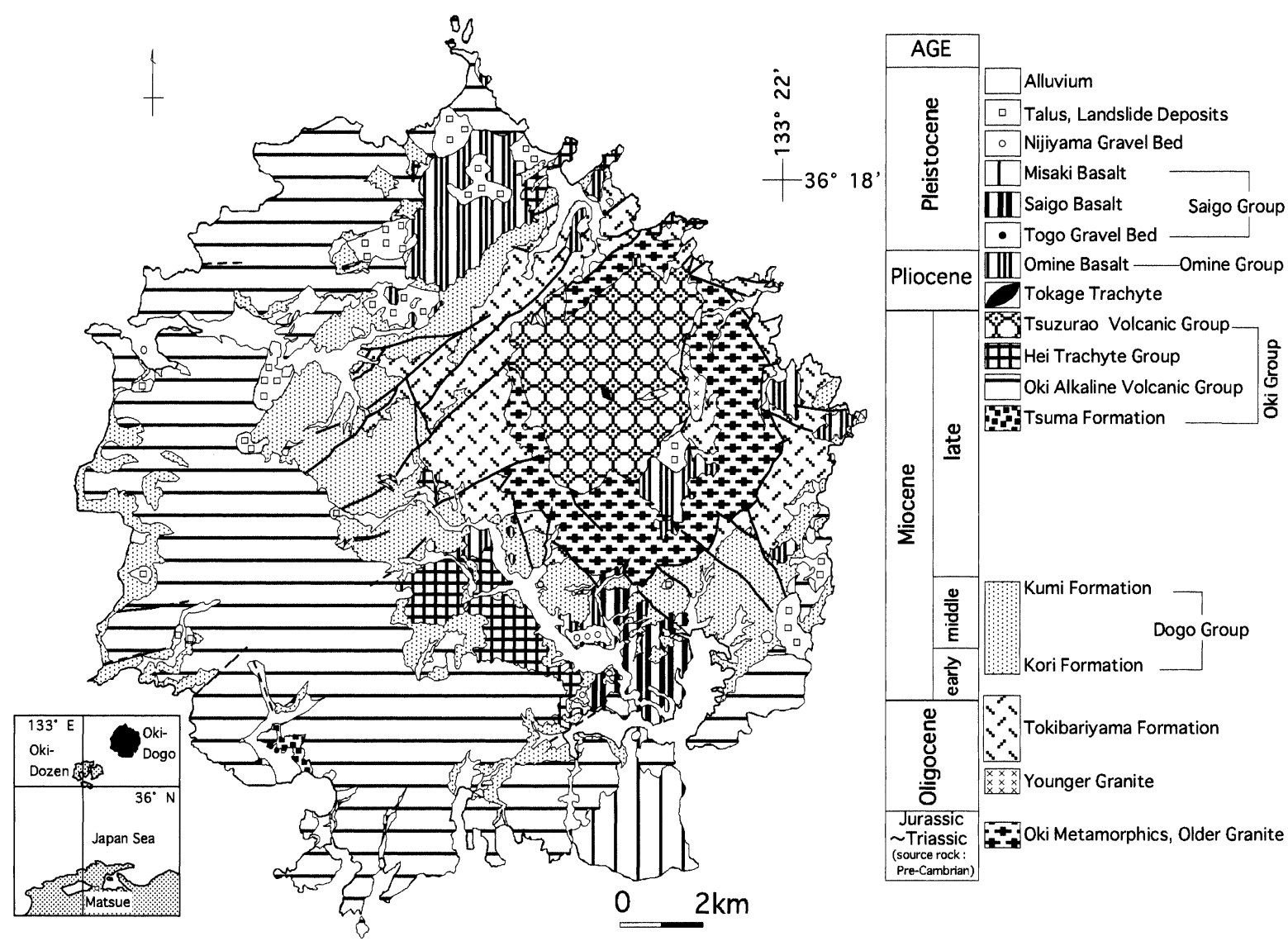

Fig. 1. Geological map of Oki-Dogo Island (modified from Yamasaki, 1998). Distribution of the Tsuzurao Volcanic Group is after Sawada et al. (1999). 


\begin{tabular}{|c|c|c|c|}
\hline A & & & \\
\hline $\mathrm{AGE}$ & Group & Rock type & \\
\hline ब. & Omine Group & $\begin{array}{l}\text { Basalt } \\
(\triangleleft 4.38 \pm 0.23 \mathrm{Ma}, 2.81 \sim 2.35 \mathrm{Ma}, \\
\triangle 3.61 \sim 3.3, \quad \bigcirc 4.6 \mathrm{Ma})\end{array}$ & \\
\hline \multirow{5}{*}{ 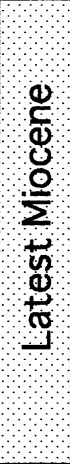 } & & Trachyte (Tokage Trachyte) & \multirow{4}{*}{$\begin{array}{l}\text { Stratigraphic } \\
\text { classification } \\
\text { from Uchimizu (1966) }\end{array}$} \\
\hline & $\begin{array}{l}\text { Tsuzurao Volcanic } \\
\text { Group }\end{array}$ & $\begin{array}{c}\text { Trachyte } \\
(ఓ 5.45 \pm 0.17 \mathrm{Ma})\end{array}$ & \\
\hline & Hei Trachyte Group & Trachyte & \\
\hline & $\begin{array}{l}\text { Oki Alkaline Volcanic } \\
\text { Group }\end{array}$ & \begin{tabular}{cc}
\multicolumn{2}{c}{ Shoshonite } \\
$(\bigcirc 5.7 \sim 5.4 \mathrm{Ma}, \diamond 5.45 \pm 0.21$, (O5.4Ma $)$ \\
Rhyolite $\quad$ Trachyte \\
$(\diamond 5.5 \sim 5.4 \mathrm{Ma})$ & $(\diamond 5.51 \pm 0.18 \mathrm{Ma})$
\end{tabular} & \\
\hline & Tsuma Formation & $\begin{array}{l}\text { Nakazato Tuffaceous Sandstone Member } \\
\text { Kamaya Sandstone Member }\end{array}$ & from Yamasaki (1998) \\
\hline
\end{tabular}

\section{B}

\begin{tabular}{|c|c|c|}
\hline$A G E$ & \multicolumn{2}{|l|}{ Rock Groupand Jye } \\
\hline \multirow{2}{*}{ बढ } & $\begin{array}{c}\text { Omine Group } \\
\text { Basalt }(\triangleleft 4.38 \pm 0.23 \mathrm{Ma}, 2.81 \sim 2.35 \mathrm{Ma} \text {, }\end{array}$ & \\
\hline & $\triangle 3.61 \sim 3.3,(04.6 \mathrm{Ma})$ & Trachyte(Tokage Trachyte) \\
\hline \multirow{5}{*}{ 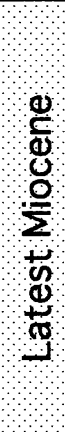 } & $\begin{array}{c}\text { Hei Trachyte Group } \\
\text { Trachyte }\end{array}$ & 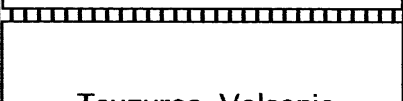 \\
\hline & $\begin{array}{c}\text { Oki Alkaline Volcanic Group } \\
\text { Shoshonite } \\
(\bigcirc 5.7 \sim 5.4 \mathrm{Ma}, \quad 5.45 \pm 0.21, \text { } 5.4 \mathrm{Ma})\end{array}$ & $\begin{array}{l}\text { Tsuzurao Volcanic } \\
\text { Group }\end{array}$ \\
\hline & $\begin{array}{ll}\text { Rhyolite } & \text { Trachyte }\end{array}$ & \multirow{3}{*}{$\begin{array}{lc}\text { Rhyolite } & \text { Trachyte } \\
& (\text { 䋆5.45 } 50.17 \mathrm{Ma})\end{array}$} \\
\hline & $\begin{array}{l}\text { Shirashima }(\diamond 5.42 \pm 0.17 \mathrm{Ma}) \text { Trachyte- } 1(\diamond 5.51 \pm 0.18 \mathrm{Ma}) \\
\text { Rhyolite }\end{array}$ & \\
\hline & $\begin{array}{l}\text { Tsuma Formation } \\
\text { Nakazato Tuffaceous Sandstone Member } \\
\text { Kamaya Sandstone Member }\end{array}$ & \\
\hline
\end{tabular}

Whole rock K-Ar age (Uto et al., 1994)

Whole rock K-Ar age (Ashraf et al., unpublished data)

(O) Whole rock K-Ar age (average) (Fujimaki et al., 1989) $\triangle$ Whole rock K-Ar age (Kaneoka et al.,1977)

K-Ar age for Sanidine (Sawada et al., unpublished data)

Fig. 2. Stratigraphy and ages of latest Miocene and early Pliocene volcanic and sedimentary rocks in Oki-Dogo island. A: for previous works, and B: for this study.

なる時張山累層, 日本海形成に伴う「リフティングステー ジ」(20〜10 Ma) のカルクアルカリ火山岩類 (一部ショ ショナイトを含む) や堆積岩類からなる郡累層と, 主に堆 積岩類からなる久見累層, 隆起, 離水し現在の島後の地形 骨格が形成された「隆起・陸化およびドーミングステージ」 (10〜 $5.5 \mathrm{Ma})$ の末期に形成された, 主に堆積岩類からなる 都万累層と大規模な中～酸性アルカリ火山岩類, そして 「傾動ステージ」(4.5〜0.6 Ma) に伴うアルカリ玄武岩類に 大分される (山崎, 1998)。陸弧ステージおよびリフティン グステージの初期から末期中新世まで，火成活動はほとん ど認められない (Fig. 1; 例えば Uchimizu, 1966; Hoshino, 1979; 小林ら, 1980; 山崎, 1998; Uto et al., 1994)。
Uchimizu (1966) によれば末期中新世のアルカリ火山岩 類の層序は, Figure 2A に示すように, 下位から「隠岐アル カリ火山岩類」(隠岐粗面岩一流紋岩類と記載), 「平粗面岩 類」,「葛尾火山岩類」(葛尾石英流紋岩類と記載), 「トカゲ 岩粗面岩」(含エジリン粗面岩質岩脈と記載) の順である。 今回の調査でも隠岐アルカリ火山岩類と平粗面岩類との上 下関係は認められた。しかしながら, 平粗面岩類の活動後 に噴出したとされる葛尾火山岩類と, 隠岐アルカリ火山岩 類や平粗面岩類との直接の関係は不明である。沢田ら (1999) の報告によれば, 葛尾山ドーム頂部には円形の凹地 があり, カルデラ状の構造を成している。葛尾火山岩類は, 主に火砕流堆積物や流紋岩溶岩からなり, この凹地を埋め 
て分布する (沢田ら，1999)。本論ではこの凹地を「葛尾山 カルデラ」と呼ぶことにする。葛尾火山岩類を貫く岩脈と して産するトカゲ岩粗面岩は, 島後に見られる他の火山岩 類とは大きく異なる全岩組成を示し (徐ら，1987; Xu, 1988; 沢田ら，2000), 独立した火山岩グループ (Uchimizu, 1966; 徐ら, 1987; Xu, 1988), または葛尾火山岩類に属する (松本, 1984) とされてきたが, その $\mathrm{Sr}$ 同位体比初生值 (SrI 值: 0.70516) は鮮新世〜第四紀の大㖓玄武岩類 $(0.70502)$ や, 藤巻ら (1991) により報告された西郷玄武岩類 (0.70490- 0.70512) の SrI值に類似している (小林ら, 2000)。以上の諸事実に基づき, 未期中新世に活動した火山 岩類についての層序関係を新たに提案し Figure 2B に示 す。Figure 2B には，すでに報告されている放射年代 (Fig. 2A）を，本論における岩石区分に対応して示す。

\section{2. 隱岐アルカリ火山岩類の地質}

Uchimizu（1966）は，島後の北東部を除く全域に分布す る鮮新統の粗面岩類と流紋岩類を一括して隠岐粗面岩一流 紋岩類とした。これは大部分が溶岩流からなり, 火砕岩は 数\%前後と少ない。その総体積は約 $21 \mathrm{~km}^{3}$ と見積もられて いる (松本, 1984)。その後, 島後北西地域にはショショナ イトのシートや溶岩も認められ, 全岩 $\mathrm{K}-\mathrm{Ar}$ 年代で見る限 りこれらのショショナイトが隠岐粗面岩一流紋岩類と, 同 時期に活動したと考えられることから，小林・沢田 (1998) はこれらを一括して「隠岐アルカリ火山岩類」と命名した。 今回, 小林・沢田 (1998) によって報告された島後北西部と 合わせて，他地域に分布する㩊岐アルカリ火山岩類につい ても詳細な地質調查を行なった。その結果, 島後南部地域 には粗面安山岩溶岩も認められた。そこで，本論では「隠 岐アルカリ火山岩類」を再定義し，島後の北東部を除く全 域に分布する末期中新世のアルカリ質火山岩類で，流紋岩 類と粗面岩類を主とし, 少量の粗面玄武岩を含むショショ ナイト，および粗面安山岩を伴う火山岩類とする。地質図， 断面図, ルート柱状図をそれぞれ Figure 3 から Figure 8 に 示した。本火山岩類は大きく下部層, 中部層, 上部層に区 分される。また各層ごとの流紋岩類の全岩化学組成 $\left(\mathrm{SiO}_{2}\right.$ 量)には違いがあり, 上部層では最も $\mathrm{SiO}_{2}$ に乏しく, 中部 層では最も $\mathrm{SiO}_{2}$ に富んでいる。また, 下部層では, 上部層 よりも $\mathrm{SiO}_{2}$ に富み，中部層よりも $\mathrm{SiO}_{2}$ に乏しい。粗面岩 類もまた層序, 岩石記載, 全岩化学組成 ( $\mathrm{Nb}$ 含有量) によ り大きく 2 つグループに区分が可能であり，下部層から 上部層で流紋岩類と互層する粗面岩類 1 , 上部層にのみ認 められる粗面岩類 2 からなる。流紋岩類については分布地 域, 記載岩石学, 全岩化学組成 (特に $\mathrm{Nb}, \mathrm{Zr}$ 含有量) に基 づきさらに細分できるので, 以下に分布地域ごとに地質お よび模式地を報告する。

(1) 島後北西部

小林・沢田 (1998) は本地域に分布する流紋岩類につい て，下部層に属し $\mathrm{SiO}_{2}$ に比較的乏しいグループを流紋岩 $\mathrm{A}$, 中部層に属し $\mathrm{SiO}_{2}$ に富むグループを流紋岩 $\mathrm{B}$ として区 分した。しかしながら, 他地域で同じころ活動した流紋岩
類とは, 岩石記載, 全岩化学組成 (特に $\mathrm{Nb}, \mathrm{Zr}$ 含有量) が 異なるため,ここではこれらを，「五箇流紋岩類」，「久斍流 紋岩類」とし，他地域の流紋岩類と区分した (Fig. 3)。火砕 岩類については, 層序学的に下位から上位に向かって火砕 岩 1 から 11 に区分できる (小林・沢田，1998)。これら火山 岩類の地質および岩相については, 小林・沢田 (1998) に詳 しく記載されているため, 以下に新たな岩石区分と名称に したがって, 各層の模式地および構成岩類のみを示す。

〈下部層〉模式地は大嶺トンネルから南東約 $300 \mathrm{~m}$ の沢 沿い, および長尾苗川中流域 (Fig. 4,ルート 5, 10)。五箇流 紋岩類の溶岩, 粗面岩類 1 の溶岩と岩床および流紋岩質 ～粗面岩質火砕岩からなる。

〈中部層〉模式地は岳山の北西約 $500 \mathrm{~m}$ の代川上流域, お よび空峰山の東方約 $600 \mathrm{~m}$ の沢の中流域から上流域 (Fig. 4, ルート 23,29)。久見流紋岩類の溶岩, 粗面岩類 1 の溶岩 と岩脈，および流紋岩質火砕岩からなる。

〈上部層〉模式地は横尾山周辺, おょび都万村の南方北側 の大嶺周辺 (Fig. 4, ルート 1,2)。主に粗面岩類 2 の溶岩か らなり, ショショナイト溶岩と岩床を伴い, それらに挟在 される粗面岩質火砕岩からなる。

(2) 島後北部

本地域の隠岐アルカリ火山岩類上部層は，主に流紋岩溶 岩とその火砕岩からなる。これは層序, 岩石記載, 全岩化 学組成 (乏しい $\mathrm{SiO}_{2}$ 量, および他の流紋岩と比較して微量 元素含有量が比較的一定の値を示す) が, 他の流紋岩類と 異なるので，ここでは「白島流紋岩類」と命名する。本流 紋岩類は, 白島海岸一帯にのみ分布し, 㥅岐アルカリ火山 岩類に属する流紋岩中最も $\mathrm{SiO}_{2}$ に乏しく, 本地域の上部層 にのみ分布する。これらは, 横尾山一帯に広く分布する粗 面岩類と同時異相であり, 火砕岩については火砕岩 12 とし て前述の火砕岩 1〜11 と区分した (Fig. 5)。

〈中部層〉本地域で見られる中部層は久見流紋岩類に属 する流紋岩溶岩とそれに挟在される火砕岩 4 および火砕岩 5 からなる。砕岩 5 は火砕流堆積物で, 伊後や西村では強 溶結しているが, 寿仙崖〜白島崎では溶結を示さないよく 成層した水中堆積物からなる。

〈上部層〉模式地は伊後の北西約 $1 \mathrm{~km}$ の沢の中流域から 上流域，および白島崎一帯 (Fig. 8，ルート C, B)。これは 中部層を整合に覆い, 白島流紋岩類の溶岩, 粗面岩類 1 の 岩脈, および流紋岩質火砕岩からなる。白島流紋岩類の溶 岩は青灰色〜灰色を示し, 一部縞状構造を示す。この溶岩 類は寿仙崖や白島崎東方約 $250 \mathrm{~m}$ の海岸で火砕岩 5 を 覆つている。隠岐白島海岸では大峯玄武岩に伴う 2 枚の玄 武岩溶岩が本火山岩類にアバットしている。

白島流紋岩類の溶岩は一枚の流紋岩質火砕岩層を挟む。 この火砕岩 12 の最大層厚は約 $50 \mathrm{~m}$ で, 下位は火砕流堆積 物からなり上位は降下火砕堆積物である。火砕流堆積物の 側方への連続性は悪く, 降下火砕堆積物のみが広範囲に分 布する。火砕流堆積物には最大 $3 \mathrm{~cm}$ の流紋岩, 黒曜石の角 礫状岩片が含まれ，降下火砕堆積物は岩片が少なく軽石と 


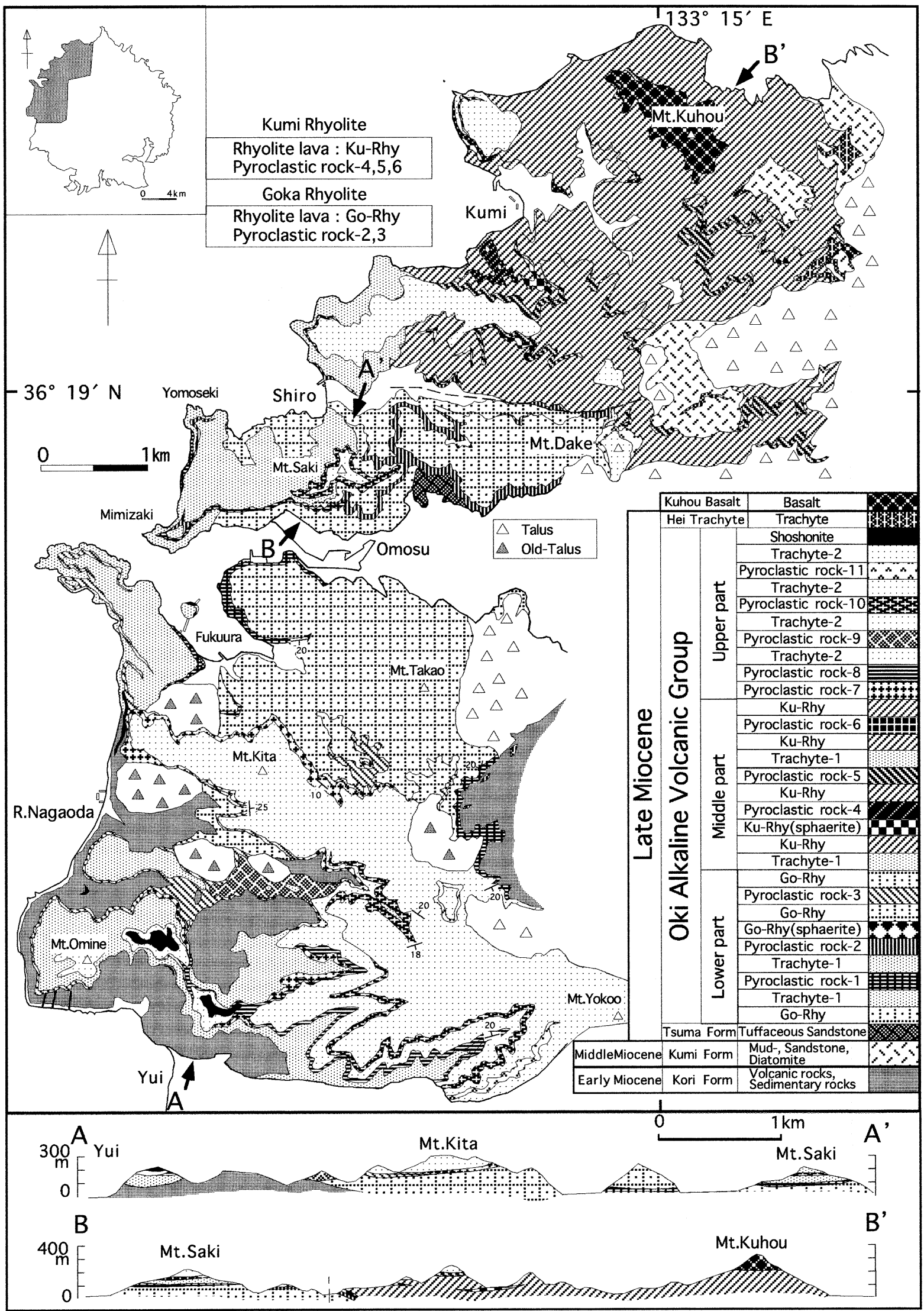

Fig. 3. Geological map and cross sections of the northwestern part of Oki-Dogo island (modified from Kobayashi and Sawada, 1998). 


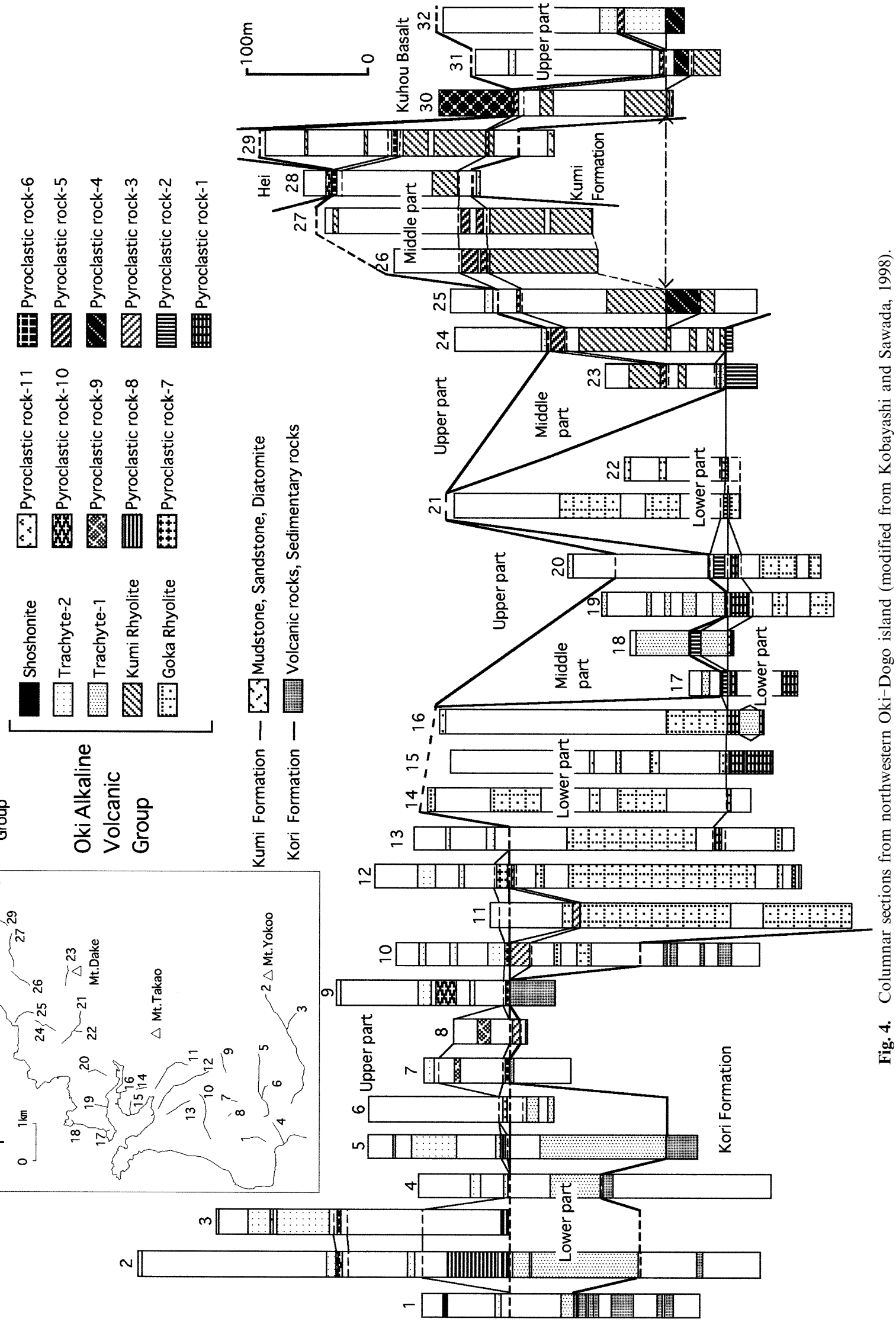




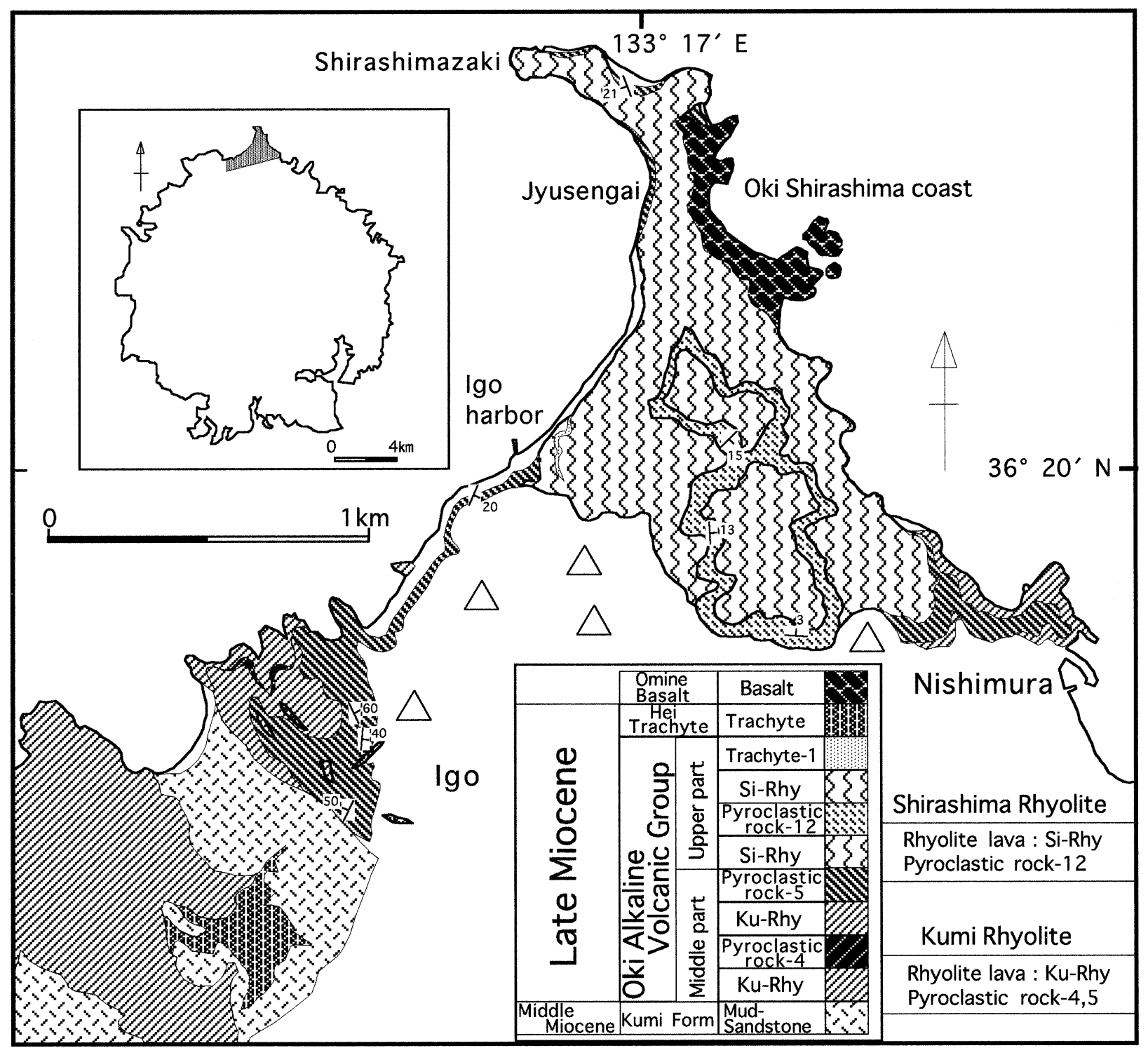

Fig. 5. Geological map of the northern part of Oki-Dogo island.

\section{火山灰に富む。}

(3) 島後南西〜南東部

本地域の隠岐アルカリ火山岩類も北西部同様, 大きく下 部層, 中部層, 上部層に区分できる。本地域の上部層に流 紋岩は見られず，下部層抒よび中部層の流紋岩類につい て, 北西部同様の $\mathrm{SiO}_{2}$ 量についての特徵が認められる。下 部層流紋岩類は広く分布しており，五箇流紋岩類の分布域 と比べても, 単一の噴出源からこれらが供給されたとは考 えにくい。そこで下部層流紋岩類をさらに二分した。また， 島後北西部の下部層, 中部層を構成する流紋岩溶岩とは岩 石記載, 全岩化学組成 (特に $\mathrm{Nb}, \mathrm{Zr}$ 含有量) が異なるた め, 本地域の下部層, 中部層流紋岩類を以下のように命名 した。

加茂流紋岩類: 隠岐アルカリ火山岩類の中部層を構成 し，小錟山一帯に分布する。
都责流紋岩類: 隠岐アルカリ火山岩類の下部層を構成 し，都万村一帯に分布する。

西郷流紋岩類: 隠岐アルカリ火山岩類の下部層を構成 し，西郷湾周辺に分布する。

本地域の下部層は粗面岩類 1 の溶岩, 都万流紋岩類およ び西郷流紋岩類の溶岩と火砕岩からなる。中部層は粗面岩 類 1 の溶岩と加茂流紋岩類の溶岩と火砕岩からなる。上部 層はショショナイトの溶岩と岩脈, 粗面安山岩の溶岩, 粗 面岩類 1 および粗面岩類 2 の溶岩と火砕岩からなる。火砕 岩類については, 層序的に下位から上位へ火砕岩 $\mathrm{a} \sim \mathrm{f}$ に区 分した。このうち $\mathrm{a}, \mathrm{b}$ は同時異相の関係にある (Fig. 6)。

〈下部層: 都万村一帯〉 模式地は高田山の東約 $500 \mathrm{~m}$ の沢 沿い，および $1.5 \mathrm{~km}$ の沢沿い (Fig. 7，ルート g, o)。本地 域の下部層は都万流紋岩類の溶岩と火砕岩からなり, 大津 久，歌木そして鳥越峠の北方で久見累層を不整合に覆い， 


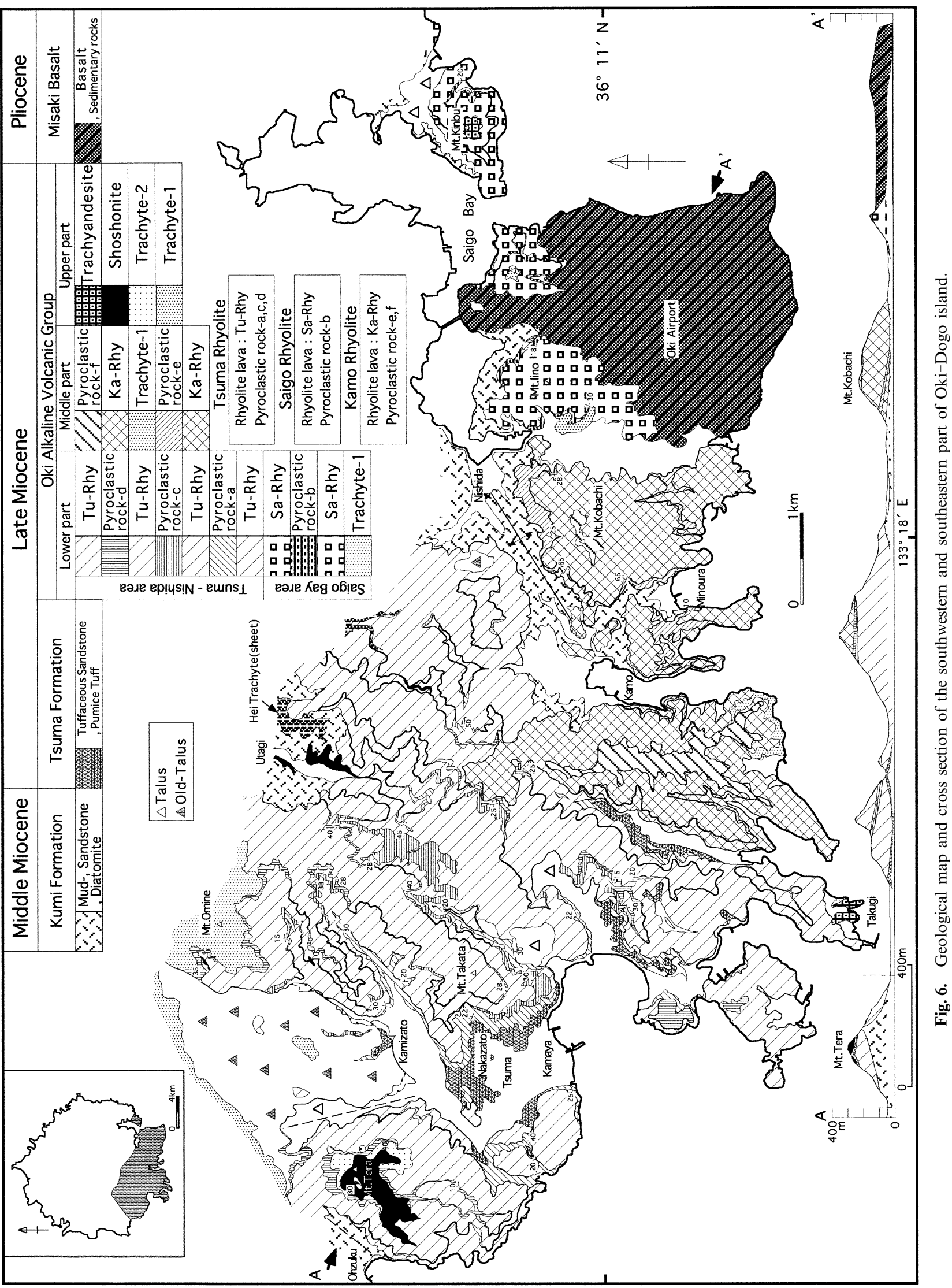



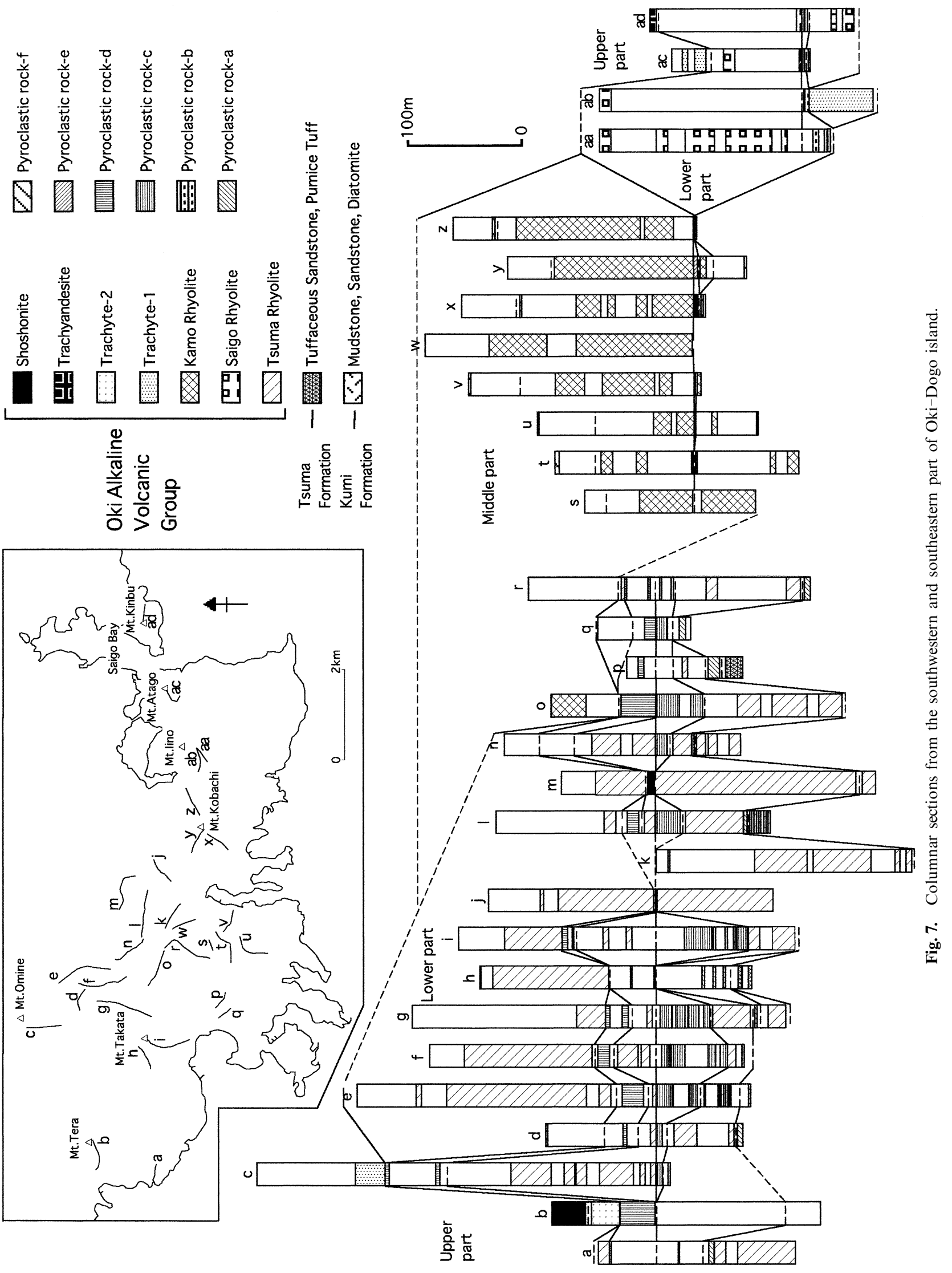
都万村中氻ざと哩金谷で都万累層を覆う。山崎 $(1984,1998)$ に よれば，都万累層は下部の釜谷砂岩部層と上部の中里凝死 質砂岩部層に区分され，後者は主によく成層した凝死岩質 砂岩で, 泥岩やシルト岩を含み, しばしば砂砶岩および黒 曜石岩片を含む酸性凝死岩を数層挟む。この凝死質砂岩部 層中には, 最大 $20 \mathrm{~cm}$, 平均約 $3 \mathrm{~cm}$ の隠岐アルカリ火山岩 類の流紋岩質两円碟や円碟も含まれることから, 都万累層 上部は，隠岐アルカリ火山岩類と指交関係にある。

都万流紋岩類の溶岩は球顆は持たないが淡赤色と白色 の流動縞状構造を示す。流紋岩溶岩は 4 層あり, その厚さ は, 最大約 150〜200 m で五箇流紋岩類の溶岩より薄く, 側 方への連続性が悪い。これらは唐尾トンネルの北約 $1 \mathrm{~km}$ の尾根で加茂流紋岩類の溶岩に覆われる。

都万流紋岩類の溶岩は 3 枚の流紋岩質火砕岩層を挟む (下から火砕岩 $\mathrm{a}, \mathrm{c}, \mathrm{d}$ )。火砕岩 $\mathrm{a}$ の岩相および層厚の側方変 化は著しく, 高田山の南南西約 $500 \mathrm{~m}$ の地点, 山里の南約 $250 \mathrm{~m}$ の沢, 壇 鏡 滝の下流域では最大層厚約 $70 \mathrm{~m}$ に達す る水中堆積物であるが, 歌木の南約 $1.3 \mathrm{~km}$ の沢 (Fig. 7, ルート n) では層厚 $1 \mathrm{~m}$ 程度の流紋岩質溶結凝灰岩であ る。前者は, 主によく成層した軽石層を多く含む凝灰質砂 岩からなり, 最大 $15 \mathrm{~cm}$, 平均約 $5 \mathrm{~cm}$ の流紋岩や黒曜石の 角䃯や亜角礫を含む。また, 本火砕岩は局所的に約 $1 \mathrm{~m}$ の 流紋岩の碟を多く含む。火砕岩 $\mathrm{c}$ は降下火砕堆積物で, 数 $\mathrm{cm}$ 程度の流紋岩質火山岩片を含む流紋岩質軽石凝灰岩か らなる。火砕岩 $\mathrm{d}$ の下位は火砕流堆積物で, 上位は降下火 砕堆積物である。前者は強溶結の流紋岩質溶結凝死岩, 流 紋岩, 黒曜石の岩片を含む非溶結火山角礫岩〜凝灰角碟岩 からなる。降下火砕堆積物は火砕岩 $\mathrm{c} に$ 比べて明らかに軽 石量に乏しく, 流紋岩, 黒曜石の岩片を含む非溶結流紋岩 質火山碩凝死岩や凝灭岩からなる。

〈下部層: 西郷湾周辺〉模式地は飯ノ山西側の採石場跡と その南側の沢沿い，および金塞山東側の沢沿い (Fig. 7, ルート aa, ab, ad)。本地域の下部層は西郷流紋岩類の溶岩 と火砕岩, 粗面岩類 1 の溶岩からなり, 飯ノ山の北西約 400 $\mathrm{m}$ の採石場跡で都万類層や久見類層を不整合に覆い，隠岐 空港一帯に分布する岬玄武岩類によって不整合に覆われ る。金峯山山頂では粗面安山岩に覆われる。

西郷流紋岩類の溶岩は淡赤色〜淡紫色と白色の流動縞 状構造を示す。本流紋岩類は火砕岩 $\mathrm{b}$ を一枚挟在する。こ れは主に降下火砕堆積物で, 流紋岩質軽石凝灰岩や流紋 岩, 黒曜石の岩片を含む流紋岩質火山碩凝灰岩からなる。 飯ノ山西側の採石場跡では, 粗面岩類 1 の溶岩を覆ってい る本火砕岩中に, 最大径 $1 \mathrm{~cm}$, 平均粒径 $4 \mathrm{~mm}$ の火山豆石 が多く見られる。上部の軽石凝灰岩は酸化し橙色を呈す。

〈中部層〉模式地は小鈥山東側の沢沿い, および神尾から 箕浦にかけての海岸沿い (Fig. 7, ルート z)。本地域の中部 層は唐尾トンネル北側で下部層を覆い, 加茂から西田にか けて久見類層を不整合に覆う。加茂流紋岩類の溶岩と火砕 岩, 粗面岩類 1 の溶岩からなる。

加茂流紋岩は淡赤色と白色の流動縞状構造や稀に球顆
状を示す。本流紋岩類は 2 枚の火砕岩 (下位から火砕岩 $\mathrm{e}$, f) を挟む。火砕岩 e の岩相および層厚の側方変化は著し く, 神尾の北西約 $500 \mathrm{~m}$ の道路沿いでは, 流紋岩, 黒曜石 の岩片を含む層厚約 $10 \mathrm{~m}$ の流紋岩質軽石凝灰岩や火山砅 凝圧岩, 加茂漁港の西側の道路沿いでは層厚数 $\mathrm{m}$ 程度の流 紋岩質火山礫凝灰岩からなる。これらは一部降下火砕堆積 物であるが, 主に火砕流堆積物からなる。加茂漁港の東側 から箕浦や西田にかけては, 砂岩層が挟在されることから 水中堆積物であると考えられる。層厚は約 $70 \mathrm{~m}$ に達し, 最 上部の一部で溶結構造が認められる。火砕岩 $\mathrm{f}$ は降下火砕 堆積物で, 流紋岩, 黒曜石の岩片を含む流紋岩質軽石凝死 岩からなる。

〈上部層〉模式地は寺山山腹の林道沿い, および蛸木の海 岸沿い。上部層は下部層を直接に覆い, 粗面岩類 1 , 粗面岩 類 2 の溶岩, ショショナイトの溶岩と岩床, 粗面安山岩の 溶岩からなる。寺山山頂ではショショナイトの溶岩が粗面 岩類 2 の溶岩を覆つている。粗面安山岩溶岩は蛸木の海岸 沿い, 金峯山山頂でのみ活動が認められる。上里の北方一 帯には大規模な崖錐堆積物が分布し, 久見累層, 都万累層, 都万流紋岩類の溶岩を覆い, 粗面岩類 1 の溶岩により覆わ れる。さらに本崖錐堆積物に含まれる岩片は, 主に流紋岩 や粗面岩であり, 軽石凝灰岩からなる降下火砕堆積物を挟 む。これらのことから, この崖錐堆積物は隠岐アルカリ火 山岩類の活動期に形成された,「古崖錐堆積物」である。古 崖錐堆積物は島後北方地域の長尾田から福浦に至るトンネ ル沿いにも認められる。

以上の地質学的諸事実は以下のようにまとめられる。

(1) 隠岐アルカリ火山岩類は下部層, 中部層, 上部層に 区分される (Figs. 8 and 9)。また流紋岩類は層序と全岩化 学組成 ( $\mathrm{SiO}_{2}$ 量) から, 上部層に属する最も $\mathrm{SiO}_{2}$ に乏しい 流紋岩類, 中部層に属する $\mathrm{SiO}_{2}$ に最も富む流紋岩類, 下部 層に属し上部層流紋岩類よりも $\mathrm{SiO}_{2}$ に富み, 中部層流紋岩 類よりも $\mathrm{SiO}_{2}$ に乏しい流紋岩類に大きく三分できる (Fig. 12)。粗面岩類は層序, 岩石記載および全岩化学組成 ( $\mathrm{Nb}$ 含有量) から, 下部層〜 上部層で流紋岩類と互層する 粗面岩および火砕岩 (粗面岩類 1), 上部層に属し, 粗面岩 類 1 に遅れて活動した粗面岩および火砕岩 (粗面岩類 2) に二分できる。また, 本火山岩類の上部層にはショショナ イト，粗面安山岩の活動も認められる。

(2) 石田 (1985) は隠岐アルカリ火山岩類 (隠岐粗面岩 一流紋岩類) の特徴について, 火砕岩に比べて溶岩が多く, その流動単位が厚く, 分布が広いとし, かなりの流動性を もって多量に噴出したと述べている。しかし, 島後北西部 に分布する隠岐アルカリ火山岩類の流紋岩類は, 下部層の 五箇流紋岩類と中部層の久見流紋岩類に二分でき，従来， 流紋岩とされた, 油井で郡累層を直接覆う溶岩が粗面岩類 1 の溶岩であることから, 流紋岩溶岩の流動単位の分布面 積は従来考えられていたほど広くはない(小林・沢田， 1998)。

本論にて報告した他地域の下部層, 中部層流紋岩類は, 


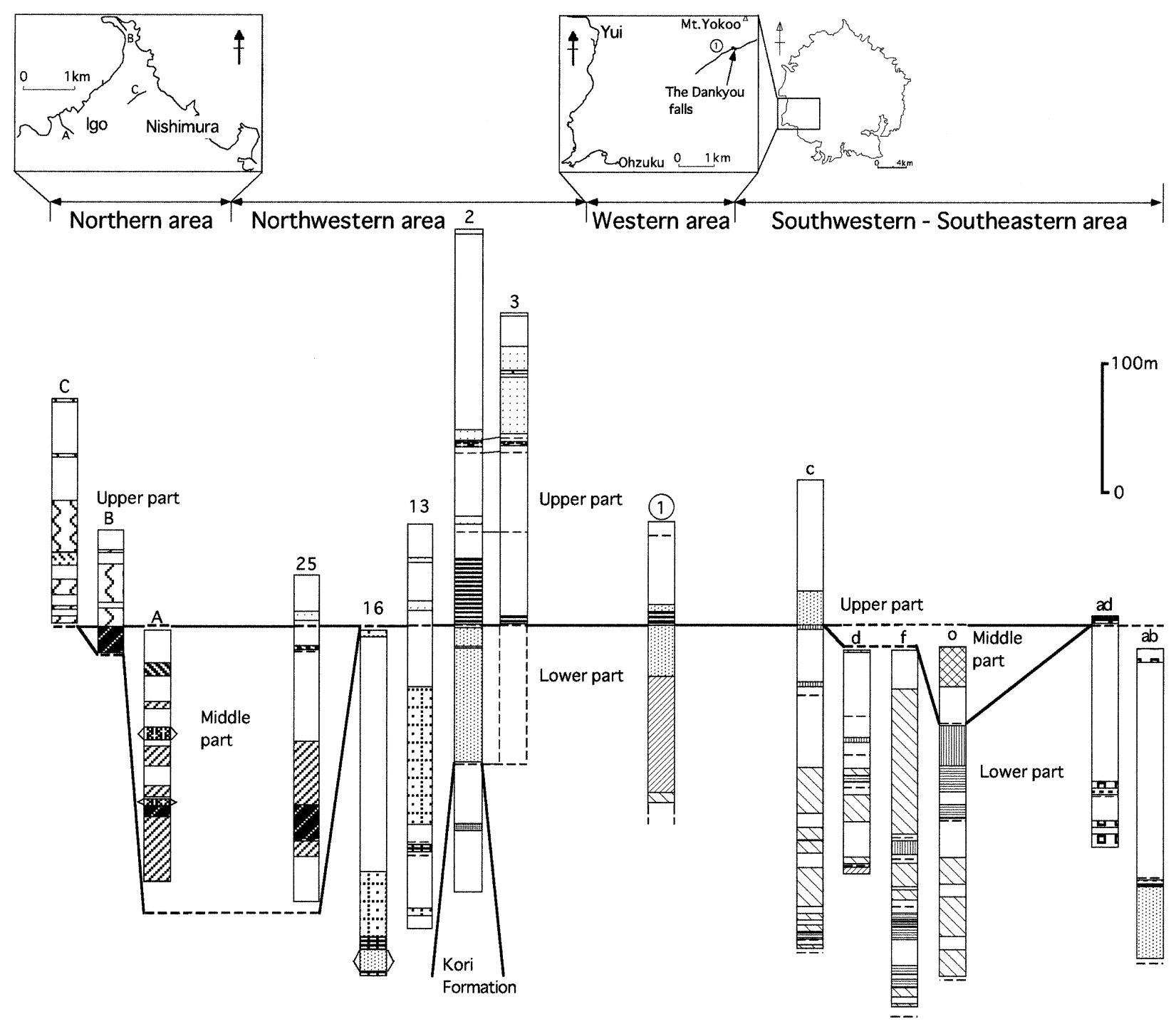

Fig. 8. Correlation of the main columnar sections of the Oki Alkaline Volcanic Group. Ornaments as in Figures 3-7.

五箇流紋岩類, 久見流紋岩類と岩石記載および全岩化学組 成 (特に $\mathrm{Nb}, \mathrm{Zr}$ 含有量) がそれぞれ異なることから，隠岐 アルカリ火山岩類の全分布域における流紋岩類は以下のよ うに細分できる。

〈島後北部〉上部層流紋岩類: 白島流紋岩類

〈島後北西部〉 中部層流紋岩類: 久見流紋岩類

下部層流紋岩類: 五箇流紋岩類

〈島後南西～南東部〉 中部層流紋岩類: 加茂流紋岩類 下部層流紋岩類: 都万流紋岩類, 西郷流紋岩類

(3) 代港南側の海岸では粗面岩類 1 のフィーダー岩脈 が認められ, また重栖港南側の採石場跡で見られる粗面岩 質火山碩凝灰岩 (火砕岩 1) には, 長径約 $0.5 \mathrm{~mm} \sim 5 \mathrm{~cm}$ の スパターと考えられるガラスレンズが多く見られることか ら, 本火砕岩類は噴出源近くで堆積した降下火砕物である と考えられている (沢田ら, 2000)。3 層認められる五箇流紋 岩溶岩のうち最も大規模な下位から 2 層準目の溶岩, 島後
北西部に分布する粗面岩類 2 の溶岩は, それらの形態から 高尾山, 横尾山付近にそれぞれ噴出源があったと考えられ る。島後南西〜南東部では, 隠岐アルカリ火山岩類の活動 期に形成された「古崖錐堆積物」の分布域が広く,さらに 流紋岩溶岩の側方への連続性が島後北西部に比べて悪いた め噴出源を特定することは困難である。しかしながら，隠 岐アルカリ火山岩類の分布域以外の地域において本火山岩 類の噴出源は全く認められないことから, 島後南西〜南東 部においても北西部同様, 現在の隠岐アルカリ火山岩類の 分布域に対応した複数の火道から供給されたと考えられ る。

\section{III. 岩石記載}

Table 1 に隠岐アルカリ火山岩類の鉱物組み合わせ, Table 2 に粗面岩類, 流紋岩類について各グループごとの斑 晶量最大時のモード組成を示した。

鉱物組成の分析は, 無水鉱物は東北大学の走査電子顕微 


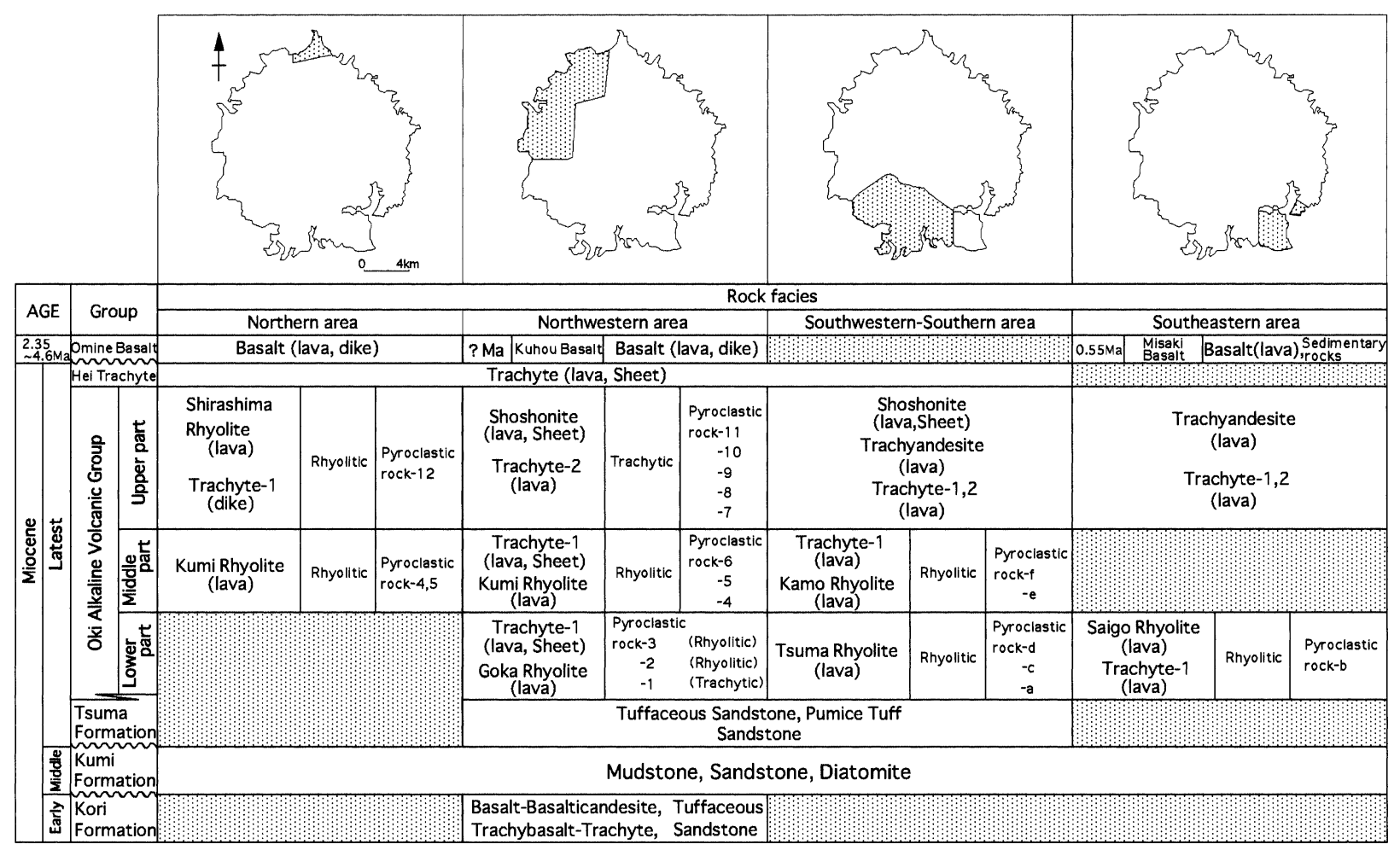

Fig. 9. Stratigraphy of the Oki Alkaline Volcanic Group in Oki-Dogo island.

鏡 (JEOL 製 JSM-5410) に搭載した，エネルギー分散型 X 線マイクロアナライザー (Oxford Link ISIS300) を用い, 加速電圧 $15 \mathrm{kV}$, ビーム電流 $50 \mu \mathrm{A}$ で行なった。補正は ZAF 法によった。含水鉱物の分析には, 島根大学汽水域研 究センター設置の X 線マイクロアナライザー (JEOL 製 JXA-8800M) を用い, 加速電圧 $15 \mathrm{kV}$, 試料電流 $2 \mathrm{nA}$ で行 なった。ビーム径は数 $\mu \mathrm{m}$ で, 測定時間はピーク位置で 10 〜20 秒, バックグランド位置で 2～5 秒で行なった。補正は ZAF 法によった。

\section{1. 流紋岩類}

下部層，中部層の流紋岩は一般に淡赤色または淡紫色を
示し, 流動縞状構造や球顆状を示す。細分される流紋岩類 の全岩化学組成には違いが認められるものの, いずれも無 斑晶質のものが多く, 斑晶はどの流紋岩類でもアルカリ長 石を主とし，鉱物組み合わせに大差はない。しかしながら， 都万流紋岩類の溶岩, 西郷流紋岩類の溶岩の斑晶量が他の 流紋岩類よりも多く，さらにアルカリ長石の組成領域が広 い。また，これらについてのみ，極く稀に石英斑晶が認め られる (Tables 1 and 2)。また, 上部層の白島流紋岩類の 溶岩は灰色を示し, 粗面岩類 2 の岩相と類似する (Tables 1 and 2)。以下にグループごとの岩石記載および鉱物組成を 報告する。五箇流紋岩類, 久見流紋岩類については小林・

Table 1. Constituent minerals for the Oki Alkaline Volcanic Group

\begin{tabular}{lll}
\hline \multicolumn{1}{c}{ Oki Alkaline Volcanic Group } & \multicolumn{1}{c}{ Phenocryst } & \multicolumn{1}{c}{ Groundmass } \\
\hline Shoshonite* & $\pm \mathrm{Pl}, \pm \mathrm{Cpx}, \pm \mathrm{Ol}$ & Pl, Cpx, Ol, Fe-Ti, gl \\
\hline Trachyandesite & $\pm \mathrm{Af}, \pm \mathrm{Pl}, \pm \mathrm{Cpx}, \pm \mathrm{Ol}$ & Af, Pl, Cpx, Ol, Fe-Ti \\
\hline Trachyte-1 & Af, $\pm \mathrm{Pl}, \mathrm{Cpx}, \mathrm{Opx}, \pm \mathrm{Bt}, \mathrm{Fe}-\mathrm{Ti}$ & Af, Pl, Cpx, Opx, Fe-Ti, Zir, Ap, gl \\
Trachyte-2 & Af, Cpx, $\pm \mathrm{Opx}, \mathrm{Fe}-\mathrm{Ti}$ & Af, Opx, Fe-Ti, Ap, gl \\
\hline Shirashima Rhyolite & Af, Cpx, Fe-Ti & Af, Fe-Ti, Zir, gl \\
Goka Rhyolite (Rhyolite A)* & Af, $\pm \mathrm{Cpx}, \mathrm{Fe}-\mathrm{Ti}$ & Af, Qz, Fe-Ti, Zir, Ap, gl \\
Tsuma Rhyolite & Af, $\pm \mathrm{Qz}, \pm \mathrm{Cpx}, \mathrm{Fe}-\mathrm{Ti}$ & Af, Qz, Fe-Ti, Zir, gl \\
Saigo Rhyolite & Af, $\pm \mathrm{Qz}, \mathrm{Fe}-\mathrm{Ti}$ & Af, Qz, Fe-Ti, Zir, gl \\
Kumi Rhyolite (Rhyolite B)* & Af, $\pm \mathrm{Opx}, \mathrm{Fe}-\mathrm{Ti}$ & Af, Qz, Fe-Ti, Zir, gl \\
Kamo Rhyolite & Af, Fe-Ti & Af, Qz, Fe-Ti, Zir, gl \\
\hline
\end{tabular}

*Kobayashi and Sawada (1998). Af, alkali feldspar; Pl, plagioclase; Qz, quartz; Cpx, clinopyroxene; Opx, orthopyroxene; Ol, olivine; Bt, biotite; Fe-Ti, Fe-Ti oxide; Ap, apatite; Zir, zircon; gl, glass. 
Table 2. Modal compositions for porphyritic trachytes and rhyolites of the Oki Alkaline Volcanic Group

\begin{tabular}{|c|c|c|c|c|c|c|c|c|}
\hline \multirow{2}{*}{$\begin{array}{c}\begin{array}{c}\text { Stratigraphic } \\
\text { classification }\end{array} \\
\text { Group }\end{array}$} & \multicolumn{3}{|c|}{ Lower part } & \multicolumn{2}{|c|}{ Middle part } & \multirow{2}{*}{$\begin{array}{c}\text { Upper part } \\
\text { Shirashima } \\
\text { Rhyolite }\end{array}$} & \multirow{2}{*}{$\begin{array}{l}\begin{array}{l}\text { Lower - } \\
\text { Upper part }\end{array} \\
\text { Trachyte-1 }\end{array}$} & \multirow{2}{*}{$\begin{array}{c}\text { Upper part } \\
\text { Trachyte-2 }\end{array}$} \\
\hline & $\begin{array}{c}\text { Goka } \\
\text { Rhyolite }\end{array}$ & $\begin{array}{c}\text { Tsuma } \\
\text { Rhyolite }\end{array}$ & $\begin{array}{c}\text { Saigo } \\
\text { Rhyolite }\end{array}$ & $\begin{array}{c}\text { Kumi } \\
\text { Rhyolite }\end{array}$ & $\begin{array}{c}\text { Kamo } \\
\text { Rhyolite }\end{array}$ & & & \\
\hline Af & 2.4 & 6.9 & 6.1 & 2.1 & 0.7 & 6.1 & 12.9 & 14.3 \\
\hline $\mathrm{Pl}$ & & & & & & & - & \\
\hline $\mathrm{Qz}$ & & - & - & & & & & \\
\hline Opx & & & & - & & & 0.2 & - \\
\hline Cpx & - & - & & & & 0.4 & 0.2 & 0.7 \\
\hline $\mathrm{Bt}$ & & & & & & & - & \\
\hline Others & 0.2 & 0.2 & 0.1 & - & 0.1 & 0.3 & 0.6 & 0.6 \\
\hline Groundmass & 97.4 & 92.8 & 93.8 & 97.9 & 99.2 & 93.3 & 86.1 & 84.4 \\
\hline Total & 100 & 100 & 100 & 100 & 100 & 100 & 100 & 100 \\
\hline
\end{tabular}

Mineral abbreviations as in Table 1. Dash (-), trace component; Blank, absent.

沢田 (1998) により流紋岩 A および流紋岩 B として，また ショショナイトについても報告されているため，本論では 省略する。

(1) 都万流紋岩類 (溶岩)

斑晶: 主にアルカリ長石で, 少量の単斜輝石や $\mathrm{Fe}-\mathrm{Ti}$ 酸 化物を伴う。極く稀に石英も認められる。アルカリ長石は コア組成が $\mathrm{Or}_{14-56}$ で, リムが $\mathrm{Or}_{14-52}$ を示し, 単一斑晶中に おいて弱い累帯構造が認められる。自形〜他形で, 一部融 食形を示す。最大長軸は $3.5 \mathrm{~mm}$ で一部集斑状を示す。単斜 輝石は非常に稀に見られ, 粒径 $0.5 \mathrm{~mm}$, 半自形〜他形で, コ アが $\mathrm{Wo}_{40-42} \mathrm{En}_{15-16} \mathrm{Fs}_{42-45}$ で, リムが $\mathrm{Wo}_{41} \mathrm{En}_{14-17} \mathrm{Fs}_{42-45}$ の 組成をもつ鉄普通輝石である。 $\mathrm{Fe}-\mathrm{Ti}$ 酸化物は主に磁鉄鉱 で, 最大 $0.5 \mathrm{~mm}$ で他形を示し, 加茂流紋岩類の溶岩に比べ て多く含まれる。

石基: ガラス基流晶質あるいは球顆状組織を示し，ガラ ス, アルカリ長石, 石英, ジルコン, $\mathrm{Fe}-\mathrm{Ti}$ 酸化物からな る。

(2) 西郷流紋岩類 (溶岩)

斑晶: 主にアルカリ長石で, $\mathrm{Fe}-\mathrm{Ti}$ 酸化物を伴う。極く稀 に石英も認められる。アルカリ長石はコアの組成が $\mathrm{Or}_{18-44}$ で, リムが $\mathrm{Or}_{11-46}$ を示す。弱い累帯構造が認められる。自 形〜他形で, 一部融食形を示す。最大長軸は $1.5 \mathrm{~mm}$ で一部 集斑状を呈す。 $\mathrm{Fe}-\mathrm{Ti}$ 酸化物は主に磁鉄鉱で, 最大 $0.2 \mathrm{~mm}$ で他形を示す。

石基: ガラス基流晶質あるいは球顆状組織を示し，ガラ ス, アルカリ長石, 石英, ジルコン, $\mathrm{Fe}-\mathrm{Ti}$ 酸化物からな る。

(3) 加茂流紋岩類 (溶岩)

斑晶: 主にアルカリ長石で, $\mathrm{Fe}-\mathrm{Ti}$ 酸化物を伴う。アルカ リ長石はコア組成が $\mathrm{Or}_{41-53}$ で, リムが $\mathrm{Or}_{39-44}$ を示す。弱い 累帯構造が認められる。一部融食形を示し, 半自形〜他形 で, 稀に自形を示す。最大長軸は $2.5 \mathrm{~mm}$ で一部集斑状を呈 す。 Fe-Ti 酸化物は主に磁鉄鉱からなり, 最大 $0.3 \mathrm{~mm}$ で他
形を示す。

石基: ガラス基流晶質あるいは球顆状組織を示し，ガラ ス, アルカリ長石, 石英, ジルコン, $\mathrm{Fe}^{-} \mathrm{Ti}$ 酸化物からな る。

(4) 白島流紋岩類 (溶岩)

斑晶: ほとんどがアルカリ長石であるが, 他の流紋岩類 と比べて単斜輝石や $\mathrm{Fe}-\mathrm{Ti}$ 酸化物を多く含む。アルカリ長 石はコアの組成が $\mathrm{Or}_{38-52}$ で, リムが $\mathrm{Or}_{28-54}$ を示し, 非常に 弱い累帯構造が認められる。最大長軸は $2.0 \mathrm{~mm}$ で, 自形 ～半自形を示し, 一部融食形を示す。単斜輝石は普通輝石 から鉄普通輝石 (コア: $\mathrm{Wo}_{36-42} \mathrm{En}_{24-32} \mathrm{Fs}_{29-34}$, リ $\left.\mathrm{Wo}_{42-43} \mathrm{En}_{21-29} \mathrm{Fs}_{29-36}\right)$ で, 最大 $1.2 \mathrm{~mm}$ の自形〜半自形を 示す。Fe-Ti 酸化物は主に磁鉄鉱からなり, 半自形〜他形で 最大粒径は $0.5 \mathrm{~mm}$ である。斑晶鉱物はしばしば集斑状を 呈する。

石基: ハイアロオフィティックまたはガラス基流晶質 で,アルカリ長石の間を埋めるように極めて細粒な鉱物が 分布する。

\section{2. 粗面岩類}

一般に灰色から黒色で斑状組織を示すが，稀に無斑晶質 である。粗面岩類は層序, 化学組成に違いがある粗面岩類 1 と粗面岩類 2 に分される。岩石記載における相違は, 粗 面岩類 1 は斜長石, 黒雲母の斑晶を稀に含むのに対し, 粗 面岩類 2 には認められないこと, またどちらの粗面岩も両 輝石を斑晶鉱物として含むが, 粗面岩類 2 には斜方輝石の 斑晶は極く稀にしか含まれないことが挙げられる (Table $1)$ 。

(1) 粗面岩類 1 (溶岩, 岩床)

斑晶: ほとんどがアルカリ長石で, 少量の斜長石, 単斜輝 石, 斜方輝石, $\mathrm{Fe}-\mathrm{Ti}$ 酸化物を伴う。アルカリ長石はコア組 成が $\mathrm{Or}_{53-57}$ で，リムが $\mathrm{Or}_{54-56}$ を示す。自形〜他形で, 一部 融食形を示し, 最大長軸 $5 \mathrm{~mm}$ である。斜長石はコア組成が $\mathrm{An}_{27-40}$, リム組成が $\mathrm{An}_{7-14}$ を示す。自形〜他形で, 一部融 


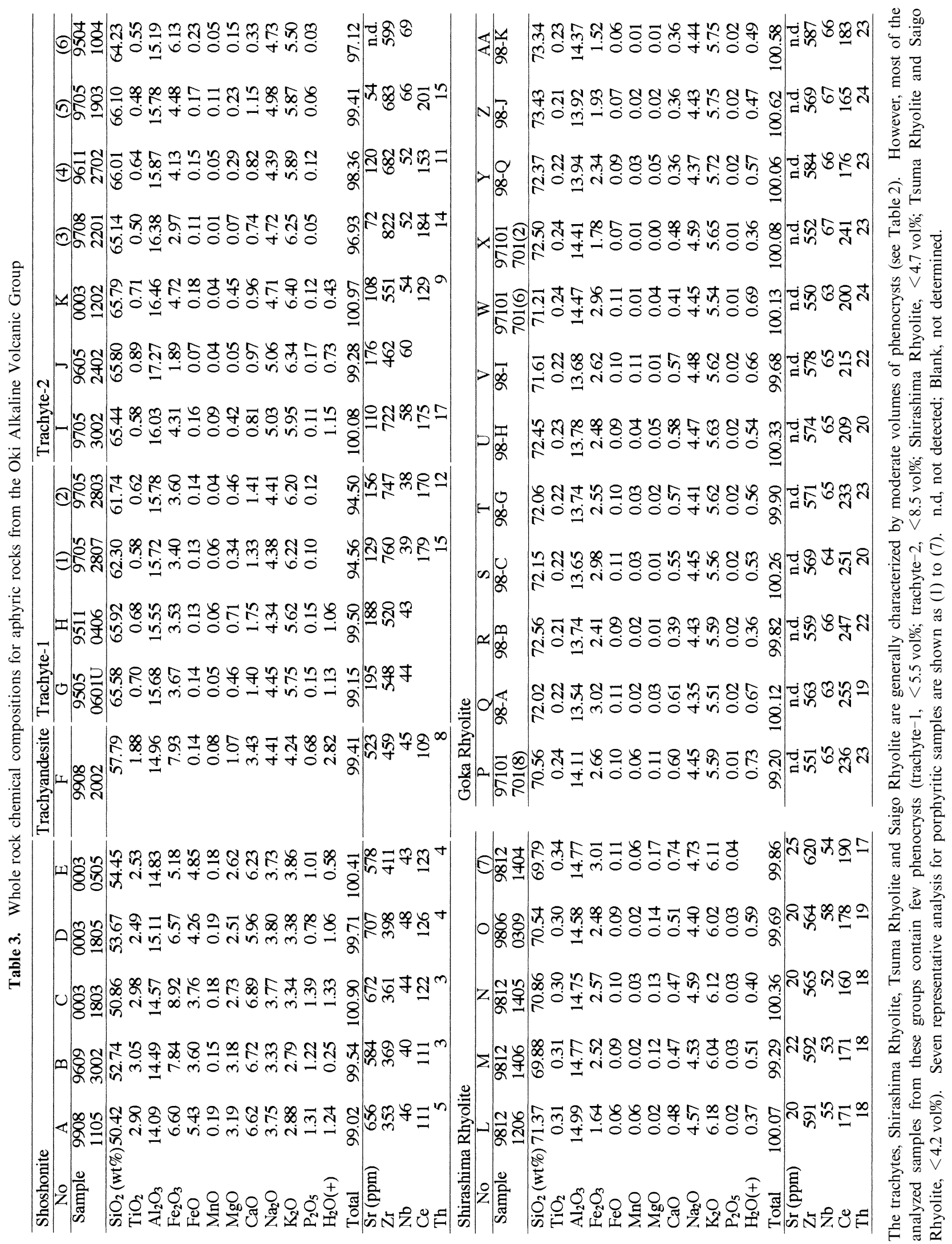




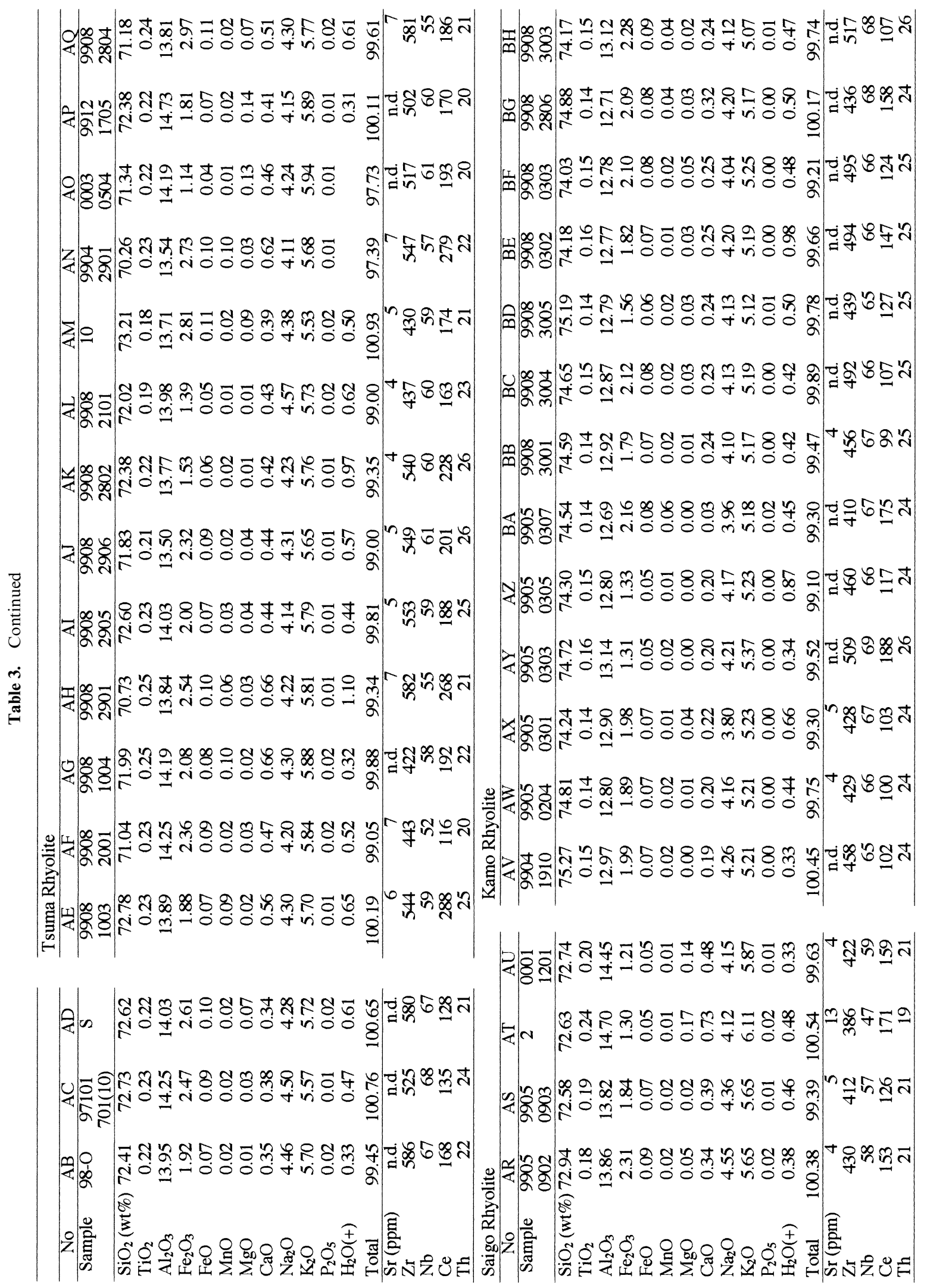


食形を示し, 最大長軸 $0.8 \mathrm{~mm}$ である。長石類の斑晶には弱 い累帯構造が認められる。普通輝石(コア: $\mathrm{Wo}_{37-42} \mathrm{En}_{36-43} \mathrm{Fs}_{19-23}$, リム: $\left.\mathrm{Wo}_{38-42} \mathrm{En}_{34-42} \mathrm{Fs}_{18-25}\right)$ は最大 $1 \mathrm{~mm}$ で自形〜他形を示す。紫蘇輝石（コア: $\mathrm{Wo}_{3} \mathrm{En}_{50-54} \mathrm{Fs}_{43-47}$, リム: $\left.\mathrm{Wo}_{3-4} \mathrm{En}_{50-54} \mathrm{Fs}_{43-47}\right)$ は他形で, 一部融食形を示し, 褐色〜淡褐色の弱い多色性を示す。最 大粒径は $1 \mathrm{~mm}$ である黒雲母は極く稀に存在し, $\mathrm{Mg} /(\mathrm{Mg}+\mathrm{Fe})$ は 0.58 である。大きさは $0.3 \mathrm{~mm}$ で融食形を 示し, 褐色から濃褐色の強い多色性を示す。Fe-Ti 酸化物は 磁鉄鉱, チタン鉄鉱からなり, 半自形〜他形で最大粒径は $0.7 \mathrm{~mm}$ である。斑晶鉱物はしばしば集斑状を呈する。

石基: 粗面岩状組織またはピロタキシティック組織を示 し，ガラス基流晶質な組織を示す場合もある。極く稀に自 形〜半自形のアパタイトを含む。

(2) 粗面岩類 2 (溶岩)

斑晶: ほとんどがアルカリ長石で, 少量の単斜輝石, 斜方 輝石, $\mathrm{Fe}-\mathrm{Ti}$ 酸化物を伴う。アルカリ長石はコア組成が $\mathrm{Or}_{45-55}$, リムが $\mathrm{Or}_{41-50}$ を示し, 弱い累帯構造が認められる。 自形〜他形で, 一部融食形を示し, 最大長軸 $3 \mathrm{~mm}$ である。 単斜輝石は普通輝石から鉄普通輝石(コア: $\mathrm{Wo}_{40-42} \mathrm{En}_{26-30} \mathrm{Fs}_{29-33}$, リム: $\left.\mathrm{Wo}_{42} \mathrm{En}_{27-30} \mathrm{Fs}_{28-32}\right)$ で, 最大 $1 \mathrm{~mm}$ で自形〜他形を示す。紫蘇輝石 $\left(\mathrm{Wo}_{3} \mathrm{En}_{51} \mathrm{Fs}_{46}\right)$ は極 く稀に認められ, 最大 $0.5 \mathrm{~mm}$ で他形を示す。 $\mathrm{Fe}-\mathrm{Ti}$ 酸化物 は主に磁鉄鉱からなり，他形で最大粒径は $0.3 \mathrm{~mm}$ である。 斑晶鉱物はしばしば集斑状を呈する。

石基: 粗面岩状またはピロタキシティック組織を示し, ガラス基流晶質組織を示す場合もある。極く稀に自形〜半 自形のアパタイトを含む。

\section{3. 粗面安山岩 (溶岩)}

灰色から黒色で，斑晶は少なく無斑晶質である。

斑晶: アルカリ長石, 斜長石, 単斜輝石, カンラン石から なる。斑晶鉱物のほとんどはアルカリ長石(コア: $\mathrm{An}_{14} \mathrm{Ab}_{55} \mathrm{Or}_{31}$, リム: $\mathrm{An}_{26} \mathrm{Ab}_{56} \mathrm{Or}_{18}$ ) と斜長石 (コア: $\mathrm{An}_{29-36} \mathrm{Ab}_{58-56} \mathrm{Or}_{8-13}$, リム: $\left.\mathrm{An}_{30-36} \mathrm{Ab}_{55-60} \mathrm{Or}_{9-10}\right)$ で, どち らの斑晶も自形〜半自形で, 最大長軸 $2 \mathrm{~mm}$ に達する。単斜 輝石 (コア: $\mathrm{Wo}_{41} \mathrm{En}_{40} \mathrm{Fs}_{19}$, リム: $\mathrm{Wo}_{43} \mathrm{En}_{34} \mathrm{Fs}_{24}$ ) は斑晶と しては稀に存在し, 半自形〜他形で, 最大粒径は $0.2 \mathrm{~mm}$ で ある。カンラン石は半自形〜他形で, 最大長軸 $0.2 \mathrm{~mm}$ であ る。多くはイディングス石に交代されている。 $\mathrm{Fe}-\mathrm{Ti}$ 酸化物 は主に磁鉄鉱からなり, 半自形〜他形で, 最大粒径は 0.5 $\mathrm{mm}$ である。斑晶鉱物は稀に集斑状を呈する。

石基: 填間組織で，アルカリ長石や斜長石の間を埋める ように, ガラスや隠微晶質な苦鉄質鉱物や $\mathrm{Fe}-\mathrm{Ti}$ 酸化物が 分布する。

\section{IV. 全岩化学組成}

\section{1. 分析方法}

全岩分析は島根大学総合理工学部地球資源環境学教室 設置の波長分散型蛍光 X 線分析装置 (リガク製 RIX2000) を用い, ガラスビード法で行なった。試料と融剤の希釈率
は $1: 5$ 法 (試料: 融剂 $\mathrm{Li}_{2} \mathrm{~B}_{4} \mathrm{O}_{7}=0.7 \mathrm{~g}: 3.5 \mathrm{~g}$ ) (沢田ら, 1997) と 1:2 法 (小林・沢田，1998) を併用した。1:2 法は 試料と混合融剤 $\left(\mathrm{LiBO}_{2}: \mathrm{Li}_{2} \mathrm{~B}_{4} \mathrm{O}_{7}=1: 4\right)$ の割合を $1.8 \mathrm{~g}$ : $3.6 \mathrm{~g}$ とし, 分析方法は Kimura and Yamada (1996) に準拠 した。補正計算法はいずれも主成分の補正係数は多重回帰 法で求め, 微量成分 $(\mathrm{Sr}, \mathrm{Zr}, \mathrm{Nb}, \mathrm{Ce}, \mathrm{Th})$ に関しては Peak over back 法を用いた。なお, $\mathrm{FeO}$ は過マンガン酸カリ滴定 法, $\mathrm{H}_{2} \mathrm{O}(+)$ は重量法により定量した。流紋岩類および粗 面岩類の $\mathrm{FeO}, \mathrm{Fe}_{2} \mathrm{O}_{3}$ については, 過マンガン酸カリ滴定法 により求めた $\mathrm{FeO}$ の平均值 (18 試料) を用いて, $\mathrm{Fe}_{2} \mathrm{O}_{3}$ を 全鉄 $\left(\mathrm{Fe}_{2} \mathrm{O}_{3}\right.$ total $)$ の $0.96( \pm 0.01: 3 \sigma)$ 重量比として求め た。

隠岐アルカリ火山岩類中の無斑晶質岩 (一部, 少量の斑 晶を含む試料を含む) の化学組成及び試料採取地点を Table 3, Figures 10 と 11 にそれぞれ示す。

\section{2. 分析結果}

Figure 12 の $\mathrm{SiO}_{2}$-Total Alkalis 図に示されるように, 隠 岐アルカリ火山岩類中のショショナイト, 粗面安山岩, 粗 面岩類の全岩組成は連続しており，これまで報告されてき たショショナイトと粗面岩類との間における組成ギャップ (Uchimizu, 1966; Xu, 1988; 小林・沢田，1998) は存在しな い。粗面岩類, 流紋岩類については Figure 13 に液組成を示 す無斑晶質岩または極く少量の斑晶を含む岩石の組成をプ ロットした。

粗面岩類は, 前述のように粗面岩類 1 および粗面岩類 2 に区分される。これらは Nb 含有量が異なり, 粗面岩類 1 の $\mathrm{Nb}$ 含有量が 35-50 ppm であるのに対し, 粗面岩類 2 は4975 ppm と比較的高い值を示す (Fig. 13a)。流紋岩類は各グ ループについて $\mathrm{SiO}_{2}$ 含有量, 微量元素含有量 (特に $\mathrm{Nb}$, $\mathrm{Zr})$ に違いがある (Fig. 13a, b)。以下に各層序ごとの流紋 岩類についての組成的特徵を示す。

\section{（1）下部層流紋岩類}

五箇流紋岩類, 都万流紋岩類, 西郷流紋岩類は, 中部層 の流紋岩類に比べて $\mathrm{SiO}_{2}$ に比較的乏しく，71.4-73.6 wt\% の狭い範囲にプロットされる。 $\mathrm{Fe}_{2} \mathrm{O}_{3}$ を除く主要元素もま た狭い組成範囲を示し，各グループ間に組成差は認められ ない。しかしながら $\mathrm{Nb}$ 含有量について五箇流紋岩類が6279 ppm を示すのに対し, 都万流紋岩類, 西郷流紋岩類はそ れぞれ 52-61 ppm, 47-59 ppm と比較的低い值を示す。

\section{（2）中部層流紋岩類}

久見流紋岩類, 加茂流紋岩類は下部層の流紋岩類に対し $\mathrm{SiO}_{2}$ に比較的富み, 74.7-75.7 wt\%の狭い範囲にプロットさ れる。この 2 つの流紋岩は $\mathrm{Fe}_{2} \mathrm{O}_{3}$ を除く主要元素もまた狭 い組成範囲を示し，2つのグループ間に組成差は認められ ない。しかしながら $\mathrm{Nb}$ 含有量について久見流紋岩類が75$91 \mathrm{ppm}$ を示すのに対し, 加茂流紋岩類は比較的低い值, 65$69 \mathrm{ppm}$ を示す。また，Zr 含有量について久見流紋岩類が 292-359 ppm を示すのに対し, 加茂流紋岩類は比較的高い 值，410-517 ppm を示す。 


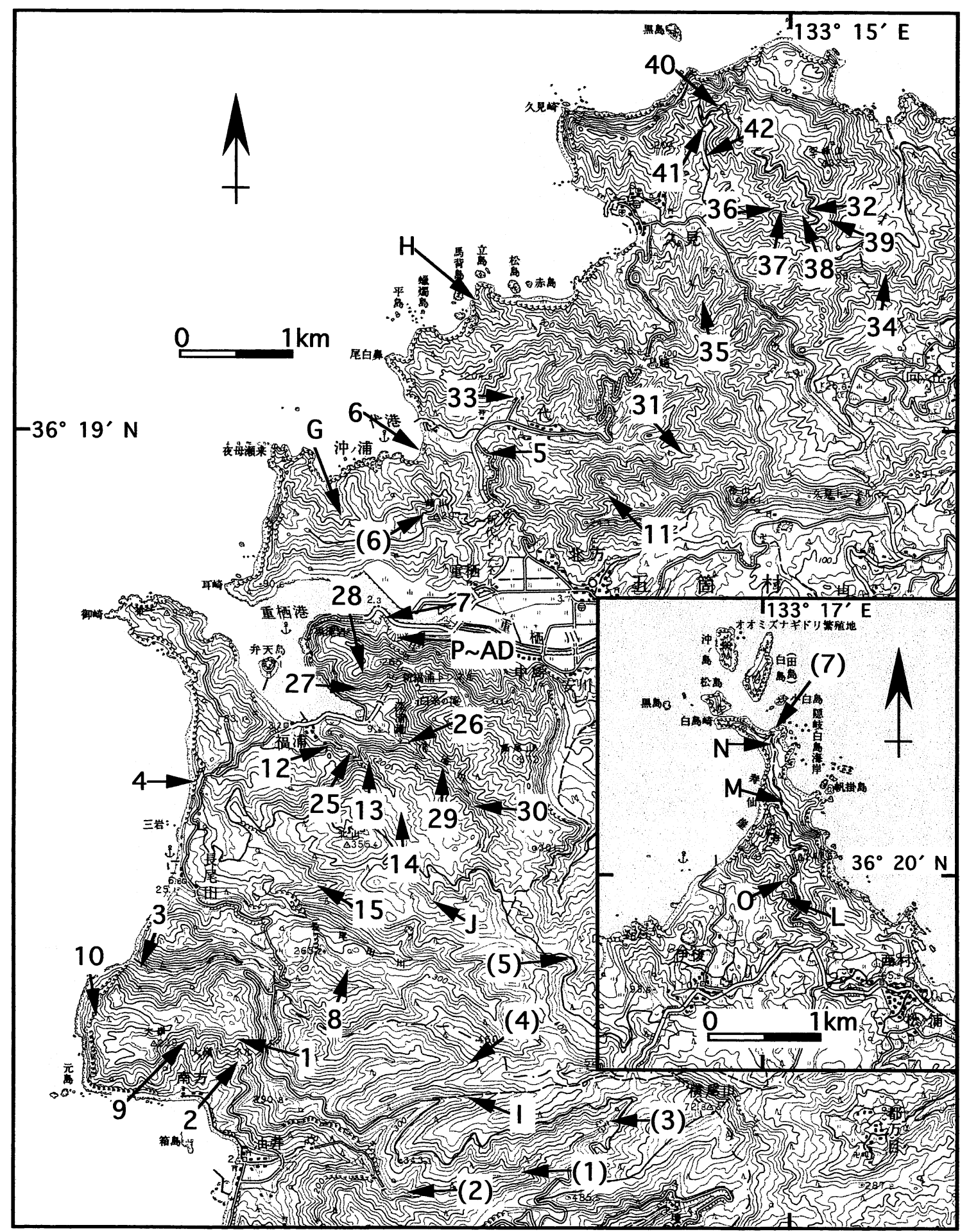

Fig. 10. Map showing sample localities in the northern part of Oki-Dogo. The topographic base map is the 1/50,000 scale map sheet "Saigo", published by the Geographical Survey Institute of Japan. Roman characters and (1) to (7) show the locations of analyzed samples listed in Table 3. Numbers show the location of analyzed samples in Kobayashi and Sawada (1998). (1-4, Shoshonite; 5-10, Trachyte-1; 11-30, Goka Rhyolite; 31-42, Kumi Rhyolite) 


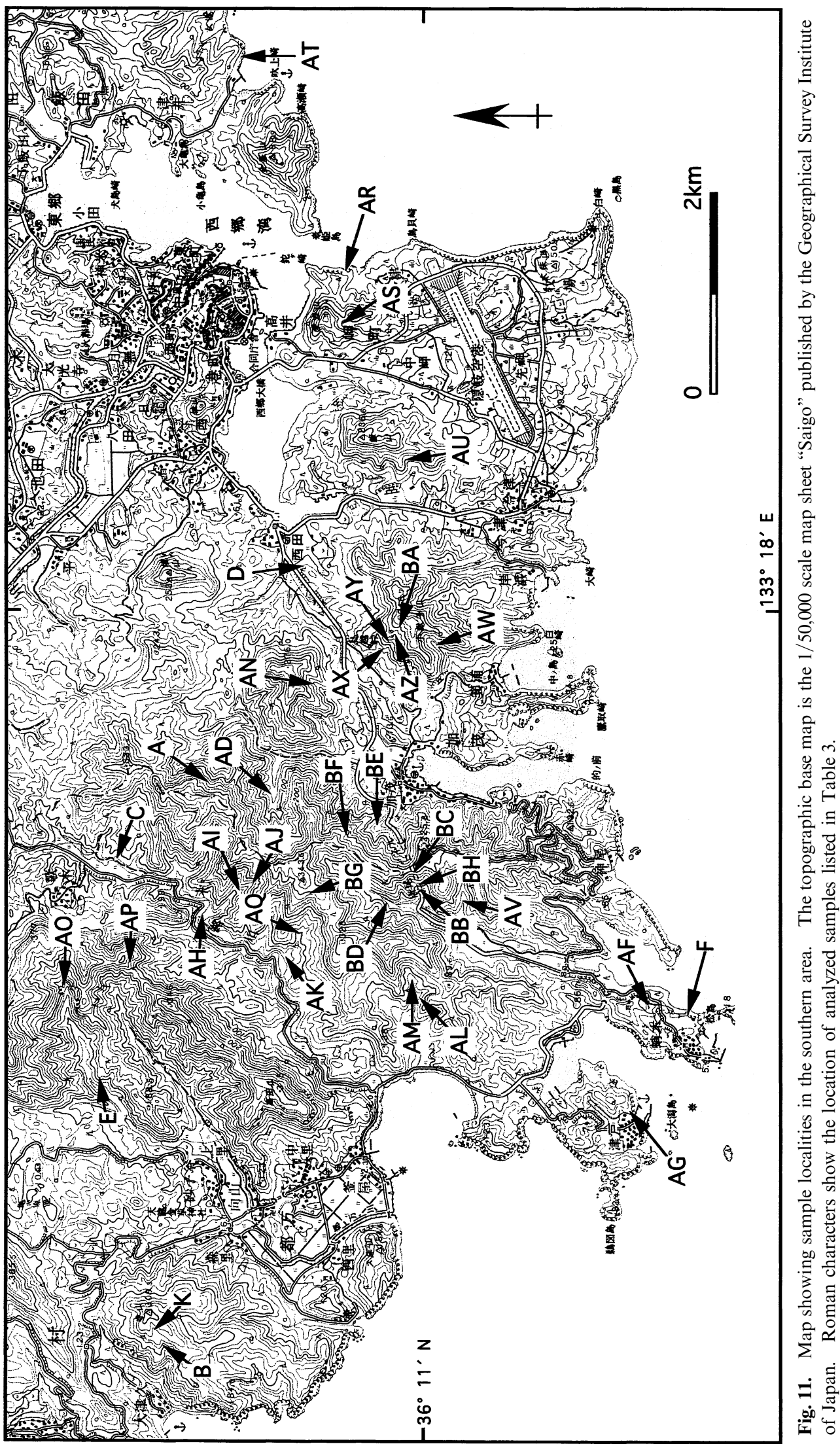




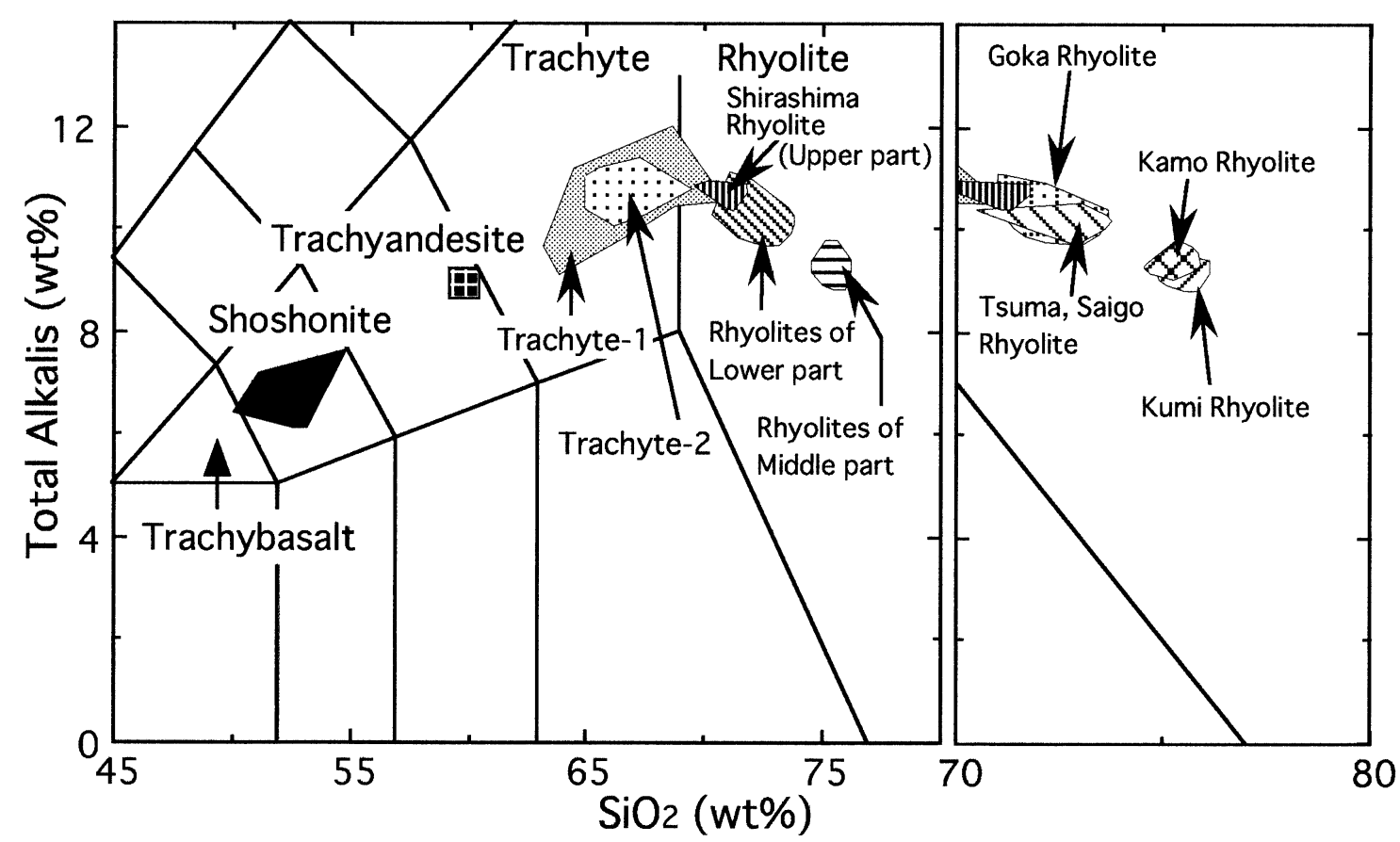

Fig. 12. Total alkali-silica diagram for the Oki Alkaline Volcanic Group. Major element compositions are normalized to $100 \%$ on water-free basis. The boundaries are after Le Bas et al. (1986).

\section{(3) 上部層流紋岩類}

白島流紋岩類は，下部層および中部層流紋岩類に比べ $\mathrm{SiO}_{2}$ に最も乏しく 70.7-71.6 wt\%の範囲にプロットされ る。また, 下部層, 中部層流紋岩類がほとんど $\mathrm{Sr}$ を含まな い $(<13 \mathrm{ppm})$ のに対して比較的高い值, 20-22 ppm を示 す。また，次に示すような他の流紋岩類に見られる特徴的 な組成変化は示さない。

\section{3. 各流紋岩グループ内にみられる特異な組成変化}

小林・沢田 (1998) は, 五箇流紋岩類, 久見流紋岩類につ いて，それぞれのグループ内で, $\mathrm{SiO}_{2}$ の変化に比べ $\mathrm{Fe}_{2} \mathrm{O}_{3}$, 微量元素含有量 (特に Y, Ce, Th) が著しく変化する特徴 的な組成変化を記載した。その成因として, 部分融解域で の残存固相中における副成分鉱物 (磁鉄鉱, アパタイト, ガーネット等) の有無と量比，または起源物質中における 量比の違いによって生じた, 元素含有量が異なるマグマの 混合によって形成可能であると論じた。Figure 13c, d で示 されるように, これら 2 つ流紋岩類の他に, 都万流紋岩 類 (下部層), 加茂流紋岩類 (中部層) についても同様な組 成変化が認められる (西郷流紋岩類は分布域が狭く, 試料 数が少ないため不明)。なお, 中部層の久見流紋岩類と加茂 流紋岩類を比べると, 前者の Th 含有量が 21-32 ppm の組 成幅をもつのに対し, 後者は 24-26 ppm で, ほとんど変化 しない。

\section{V. 考 察}

1. 隠岐アルカリ火山岩類のマグマ供給系

隠岐アルカリ火山岩類の噴出源について, Uchimizu (1966) は, 島の縁辺地域の多くの火道から噴出したとし,
約 20 の火道を報告した。さらに, 松本 (1984) は, 本火山 岩類が環状割れ目から噴出したとし, 島後におけるカルデ ラ説を唱えた。

地質の項で述べたように隠岐アルカリ火山岩類は, 全島 的にみて大きく下部層, 中部層, 上部層に区分され, これ らを構成する粗面岩類および流紋岩類は, 層序, 岩石記載, 鉱物組成, 全岩化学組成に基づき, 6 種類の流紋岩類 (下部 層: 五箇流紋岩類, 都万流紋岩類, 西郷流紋岩類; 中部層: 久見流紋岩類, 加茂流紋岩類; 上部層: 白島流紋岩類) と 2 種類の粗面岩類 (下～上部層: 粗面岩類 1 ; 上部層: 粗面岩 類 2) に細分される。特に流紋岩類については，6 種類の流 紋岩類がそれぞれ限られた地域に分布し, 中部層流紋岩類 は,下部層流紋岩類に比べて $\mathrm{SiO}_{2}$ に富むという層序に対応 した組成変化が認められる。さらに分布地域の異なる $2 つ$ の中部層流紋岩類は, $\mathrm{Nb}, \mathrm{Zr}$ 含有量がそれぞれ異なり, Th についても異なる挙動を示す。これらのことは, Uchimizu (1966) が指摘したような, 複数の異なる火道から本火山岩 類が噴出したとする考えを支持する。さらに，松本 (1984) がカルデラ形成モデルにより説明したように, 隠岐アルカ リ火山岩類の分布は現在の海岸線に沿って環状に分布し, その内側である島後北東部には分布しない。このことは， 本火山岩類を供給した複数の火道群の位置を規制するよう な, 環状構造の存在を考える必要がある。山崎 (1998) は, 26〜23 Ma の時張山累層の形成時期に大規模なコールドロ ンが存在したと考え，末期中新世には大量の中～酸性アル カリ火山活動に伴い, 葛尾山ドームを中心としたドーム状 の隆起運動が島後全島にわたり起きたと考えている。した がって, 隠岐アルカリ火山岩類の環状分布は, 後期漸新世 

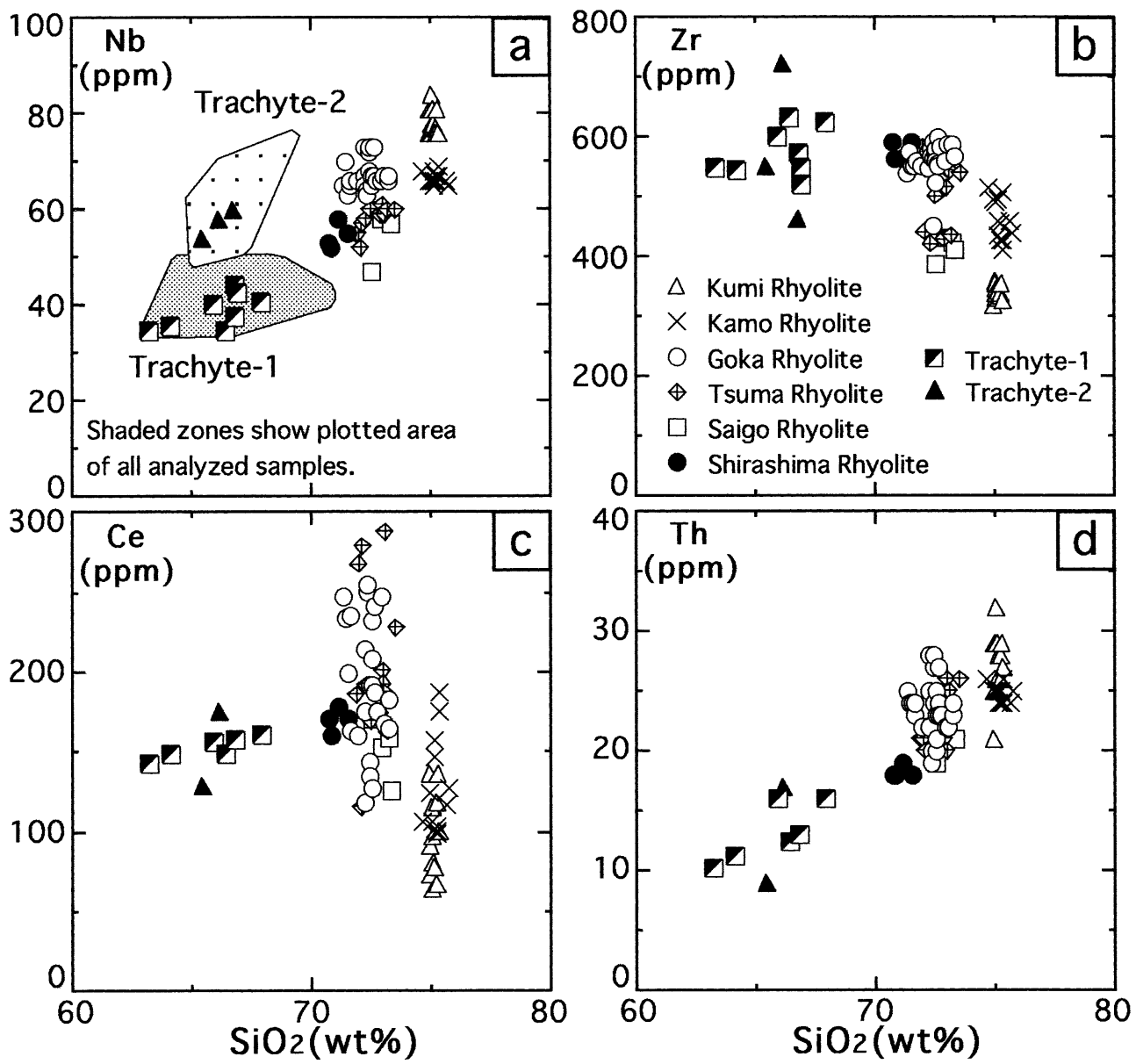

Fig. 13. Trace elements-silica variation diagrams for aphyric trachytes and rhyolites of the Oki Alkaline Volcanic Group. Modal compositions for selected samples are given in the footnotes of Table 3.

(a) $\mathrm{Nb}$ : $\mathrm{Nb}$ contents of trachyte-1 are lower than those of trachyte- 2 . Nb contents of rhyolites in the southwestern and southeastern areas are lower than those in northwest Oki-Dogo.

(b) Zr: For rhyolites of the middle stage, Kamo Rhyolites have greater Zr contents than do Kumi Rhyolites. This is contrary to the relation in $\mathrm{Nb}$ contents between those rhyolites.

(c) $\mathrm{Ce}$ : Ce contents within each rhyolite group vary between factors of 1.9 to 2.5 times, compared with restricted $\mathrm{SiO}_{2}$ variation of only 71.4 to $73.6 \mathrm{wt} \%$ for early stage rhyolites, and 74.7 to $75.7 \mathrm{wt} \%$ for middle stage rhyolites. Similar variation of other trace elements in Goka Rhyolite and Kumi Rhyolite are demonstrated by Kobayashi and Sawada (1998).

(d) Th: Among middle stage rhyolites, Th contents of Kumi Rhyolites vary between 21 and 32 ppm, whereas Kamo Rhyolites show a narrower range, from 24 to $26 \mathrm{ppm}$.

に形成されたコールドロンの環状割れ目を通ってマグマが 上昇したか, あるいは末期中新世のドーム状隆起に伴って 形成された環状割れ目を火道としてマグマが上昇した結果 と考元られる。

\section{2. 下部層・中部層流紋岩類の形成}

流紋岩マグマの成因について，小林・沢田 (1998) は, $\mathrm{An}^{-} \mathrm{Qz}^{-} \mathrm{Ab}-\mathrm{Or}$ 系において隠岐北西部に分布する五箇流 紋岩類, 久見流紋岩類のノルム組成がそれぞれ異なる領域 に集中し，それらの間に中間組成がないことを理由の一つ として, 各流紋岩マグマは最低共融点 (cotectic point) にお ける地凯物質の部分融解によって, それぞれ別個のマグマ として生じたと報告し, Johannes and Holtz (1990) のQz$\mathrm{Ab}-\mathrm{Or}-\mathrm{H}_{2} \mathrm{O}-\mathrm{CO}_{2}$ 系での実験結果との比較から, 五箇流紋
岩類が下部地殼物質, 久見流紋岩類が中部地殼物質の部分 融解によりそれぞれ形成されたとするマグマ成因モデルを 提案した。そこで, これら流紋岩類と本論で示した他地域 に分布する下部層および中部層流紋岩類のノルム組成を， An-Qz-Ab-Or系に扔いて比較した。試料は液組成を示す 無斑晶質岩または極く少量の斑晶を含む岩石を用いた (Table 3)。ただし，流紋岩類のノルムAn は少量 (3.5 wt\% 以下) なので, $\mathrm{Qz}^{-} \mathrm{Ab}-\mathrm{Or}$ 系 (Fig. 14) で近似できる。

この図で明らかなように，本火山岩類の全分布域におけ る地質調査および岩体区分に基づく複数の流紋岩類は，小 林・沢田 (1998) で示されるように下部層, 中部層の流紋岩 類ごとにそれぞれ異なる領域にプロットされ，それら2つ の間の中間組成を示すような流紋岩は本火山岩類に存在し 


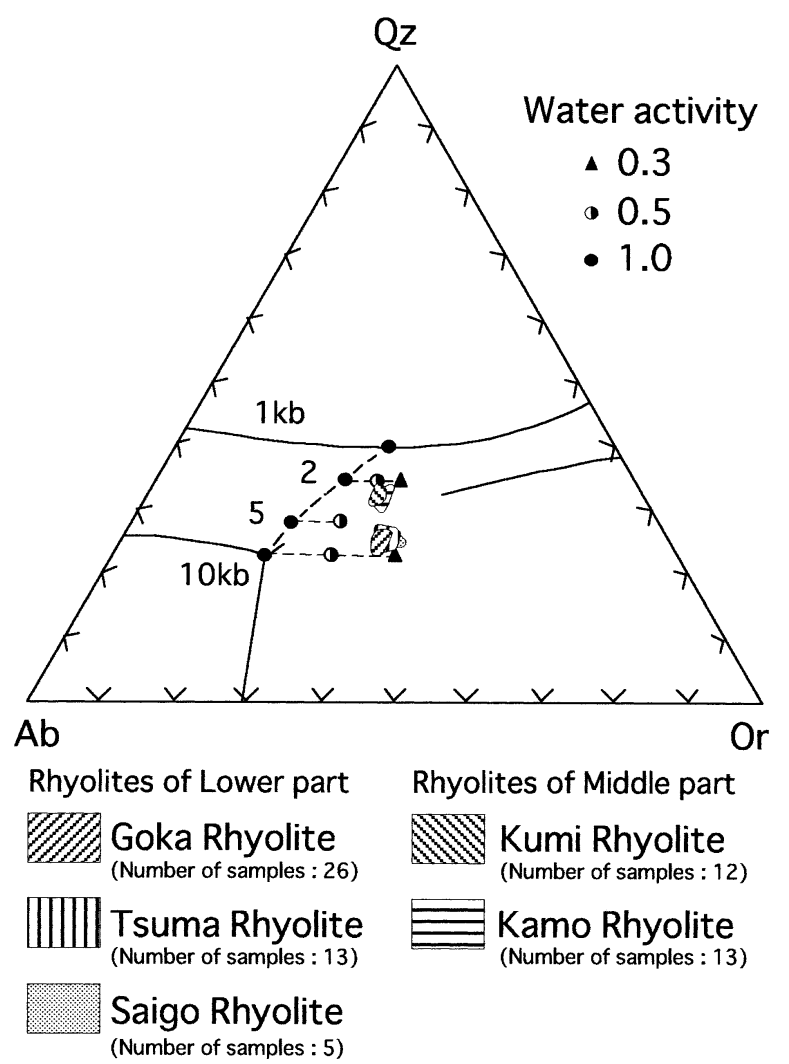

Fig. 14. Normative quartz (Qz), albite $(\mathrm{Ab})$ and orthoclase (Or) compositions for aphyric rhyolites from the lower and middle parts of the Oki Alkaline Volcanic Group. The cotectic points, phase relationships and pressures $(1,2,5,10$ kbar) in the system $\mathrm{Qz}^{-} \mathrm{Ab}^{-} \mathrm{Or}^{-} \mathrm{H}_{2} \mathrm{O}^{-} \mathrm{CO}_{2}$ are after Johannes and Holtz (1990).

ない。このことは，小林・沢田 (1998) の結論を支持してい る。しかしながら, 下部層流紋岩類については主要な斑晶 鉱物であるアルカリ長石は, 五箇流紋岩類が最大 2.4 容量 $\%$ であるのに対し，都万流紋岩類と西郷流紋岩類はそれぞれ 最大 6.9 容量 $\%, 6.1$ 容量\% と比較的多く含まれ, またこれら のグループには石英斑晶が認められる (Table 2)。アルカリ 長石の組成範囲は五箇流紋岩が $\mathrm{Or}_{41-35}$ であるのに対し, 都 万流紋岩類と西郷流紋岩類がそれぞれ $\mathrm{Or}_{56-14}, \mathrm{Or}_{46-11}$ を示 し，明らかに広い組成幅を示す。

小林・沢田 (1998) は，五箇流紋岩類，久見流紋岩類中の 珪長質斑晶鉱物としてアルカリ長石しか認められない理由 として,マグマ上昇による圧力の低下または $\mathrm{H}_{2} \mathrm{O}$ 活動度の 上昇によって, カリ長石領域が拡大したことで説明可能で あると述べている。これに対し, 都万流紋岩類, 西郷流紋 岩類では, マグマの上昇過程においてアルカリ長石の晶出 がより進行したために，マグマ組成が石英領域に達したと いう考えが最も妥当である。

\section{2 種類の粗面岩と粗面安山岩の存在}

粗面岩類の主な成因については, ショショナイトマグマ からの結晶分化作用により形成可能であるとされる一方 で, 地殼物質の部分融解による形成の可能性が検討されて きた。その理由として，ショショナイトと粗面岩類との間 に組成ギャップが存在するとされたことが挙げられる
(Uchimizu, 1966; Xu, 1988; 小林・沢田，1998)。しかしな がら, 今回, 本火山岩類には粗面安山岩の活動があり, ショ ショナイトと粗面岩類の間に組成ギャップは存在しないこ とが明らかとなった。また, 白島流紋岩類には, 他の流紋 岩グループ内に認められる様な $\mathrm{SiO}_{2}$ があまり変化しない にもかかわらず微量元素含有量が著しく変化するという特 異な組成変化が認められず, 粗面岩類からの連続的な全岩 化学組成変化を示す (Fig. 13)。ショショナイトから白島流 紋岩類にかけて見られる連続的な組成変化について検討し たモデル計算結果では，上部層の構成岩類であるショショ ナイト, 粗面安山岩, 粗面岩類 2, 白島流紋岩類が一連の結 晶分化により形成可能である (小林ら，2000)。また粗面岩 類 1 についての SrI 值 (0.70663-0.70709) は, ショショナイ トから白島流紋岩類の SrI 值 (0.70649-0.70740) の範囲に 入る (小林ら，2000)。これらのことは, 粗面岩類 1 につい ても, より苦鉄質なマグマからの結晶分化作用 (十地殼物 質の混染作用) により形成された可能性を否定しない。

\section{4. 火成活動史}

島後における末期中新世〜鮮新世の火成活動史を Figure 15 に示した。

(1) $13 \mathrm{Ma}$ 前後に始まった隆起運動により島後隆起帯 が生じ, 約 $6 \mathrm{Ma}$ には島嶼化し, その後のアルカリ火山岩類 の火成活動による島後全体のドーミングによって現在の地 

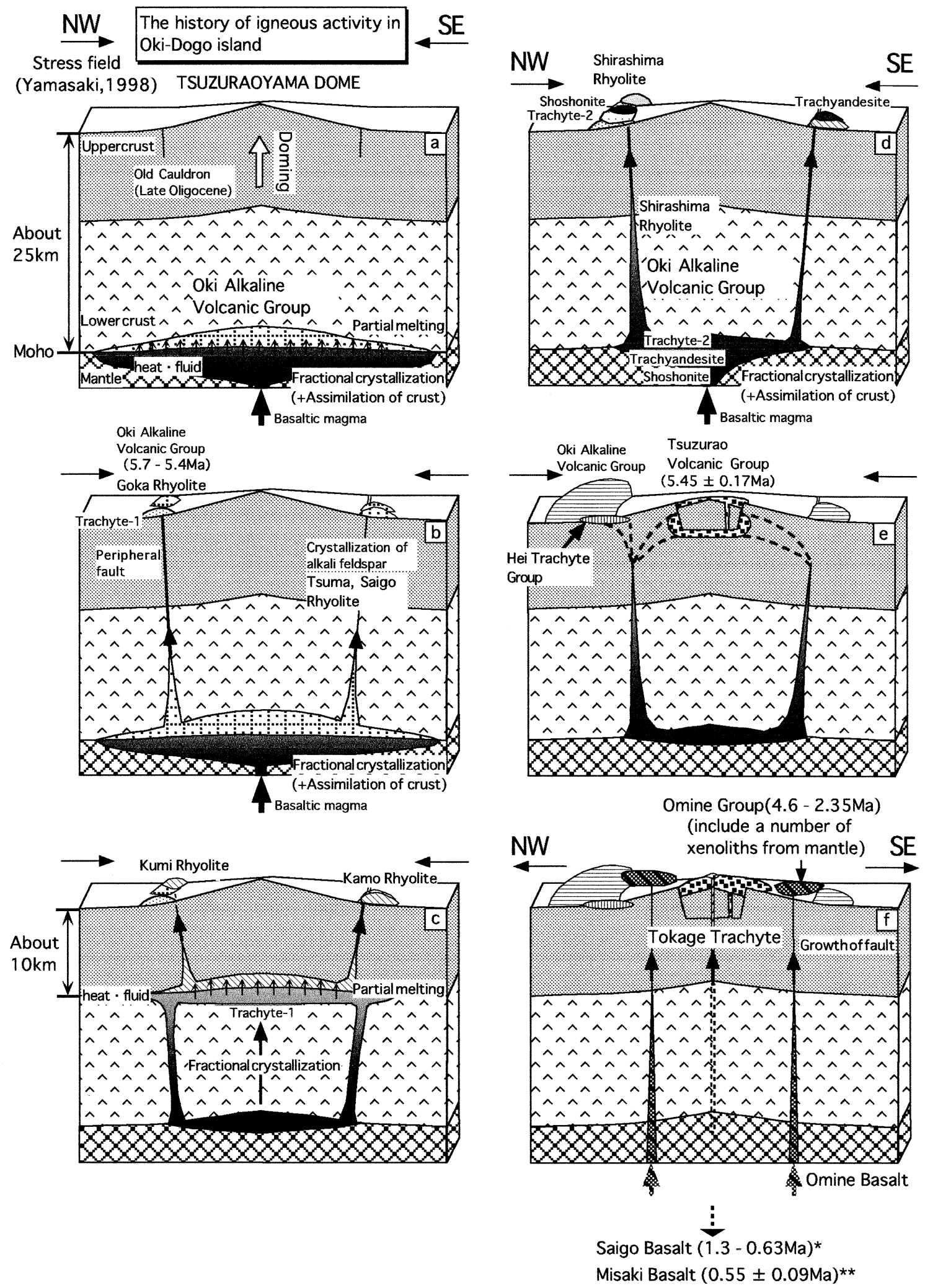

Fig. 15. History of the igneous activities (a to f) in Oki-Dogo island in the latest Miocene and early Pliocene. *Compiled data by Yamasaki (1998); **Whole rock K-Ar age after Uto et al. (1994). Other data sources are shown in Figure 2. 
形骨格が形成された（山崎，1998）。

おそらく塩基性マグマが島後下部の地殼内へ貫入し，そ の結晶分化作用に伴う潜熱や流体の供給によって下部地殼 物質 (深度約 $25 \mathrm{~km}$ ) の部分融解が起こった。その結果, 隠 岐アルカリ火山岩類の下部層流紋岩類のマグマが生じ, 地 殼中に蓄積された (Fig. 15a)。この下部層流紋岩類や, 中部 地殼物質の部分融解物である中部層流紋岩類は, 下部層か ら上部層にかけて活動が認められる粗面岩類 1 と指交関係 にある。この粗面岩類 1 の成因については, 今後の検討課 題であるが, 熱源となった塩基性マグマの結晶分化作用 (十地殼物質の混染作用) によって形成されたのではない かと筆者らは今のところ考えている。

(2) 相澤・吉田 (2000) によれば, 岩床状マグマ溜りに おいて, 下方からの $\delta_{1}$ が大きく, マグマ溜り上方の地塊を 持ち上げ隆起を起こすような場合，マグマ溜りの肩の部分 に応力が集中して環状断層が発生しやすくなる。隠岐アル カリ火山岩類の環状分布や, 火成活動に伴うドーミング現 象から, Figure 15a で形成された下部層流紋岩マグマの部 分融解域においても同様な現象が起きたと考えられる。つ まり，ドーム縁辺のより火道を形成しやすい環状部分に 沿って, 隠岐アルカリ火山岩類が複数の火道を通って噴出 したと考えられる (Fig. 15b)。

(3) 下部層流紋岩マグマの噴出が終わり, 熱源であった 塩基性マグマかあるいはその分化物である粗面岩質マグマ が上昇して中部地殼物質 (深度約 $10 \mathrm{~km}$ ) の部分融解を起 こし，中部層流紋岩マグマが生じた (Fig. 15c)。

(4) 新たにショショナイト質の塩基性マグマが深部よ り供給され, 隠岐アルカリ火山岩類の最も上位で活動した ショショナイトと, その分化物である粗面安山岩, 粗面岩 類 2, 白島流紋岩類が形成された (小林ら, 2000)。ショショ ナイトマグマは, Figure 15a と同様に, 浮力中立点である下 部地款に停滞していたであろう (Fig. 15d)。しかしながら， それらを熱源として形成されたと思われる地款の部分融解 マグマは認められない。沢田・高須 (1999) は, 島根県益田 市産の含藍晶石片麻岩質捕獲岩中の部分融解ガラスの組成 と，隠岐アルカリ火山岩類の下部層流紋岩類との組成的類 似性を示すと共に, 部分融解ガラスの形成に黒雲母の脱水 分解による $\mathrm{H}_{2} \mathrm{O}$ の供給と融点降下が大きく貢献した可能 性を示している。部分融解作用において黒雲母が早期に消 失してしまうことは, 部分融解した捕獲岩類についての記 載等により, 古くより知られている (例えば, 牛来, 1940)。 これらのことから，下部層流紋岩マグマの形成の際に含水 鉱物が消失し, Figure 15d のステージでは地殼物質の部分 融解は起きなかったと考えられる。

(5) 平粗面岩類に属する粗面岩マグマが隠岐アルカリ 火山岩類を貫くシートとして貫入し, また島後北東部では 葛尾火山岩類が葛尾山カルデラを形成しながら噴出した (Fig. 15e)。これらの火山岩類についての SrI 值は, 隠岐アル カリ火山岩類のショショナイトから白島流紋岩類が示す值 (0.70649-0.70740) に対して, 平粗面岩類 (0.70904), 葛尾火
山岩類 (0.71626-0.71722) の順に高くなっている (小林ら, 2000)。これらのことは, 地殼物質の混染による影響, また は，異なるマグマ起源である可能性が考えられる。山崎 (1998) は, 平粗面岩類のシル状〜ラコリス状の貫入形態か ら, 局所的か, 広域的かは不明ながら, 圧縮応力場での活 動であったと考え, 藤巻ら (1991) による平粗面岩類の SrI 值 (葛尾火山岩類を含める) はマグマが地殼物質を混染す ることにより，同時期に活動した火山岩類よりも高い值を 示すに至ったとする解釈と調和的であるとした。隠岐アル カリ火山岩類, 平粗面岩類, 葛尾火山岩類の間におけるマ グマ間の成因については今後検討の余地はあるが, 平粗面 岩類の貫入形態から考えられるモデルとして, Yoshida (1984) が, 石錧コールドロンに拈いて考えたように, セン トラルプルトンが陥没ブロック内の浅所に岩床状に貫入す ることで, 再生カルデラが形成されたとするモデルが適用 できるかも知れない。つまり隠岐アルカリ火山岩類の最も 後期に噴出したショショナイト, 粗面安山岩, 粗面岩類 2 , 白島流紋岩類を構成したマグマの一部が，隠岐アルカリ火 山岩類の環状分布の内側境界部分に貫入して平粗面岩類を 構成し, そのマグマが地款内をさらに移動して葛尾火山岩 類を形成したと考えることができる。このモデルでは， ショショナイトから白島流紋岩類を構成したマグマと地殼 物質との混染量の違いにより, 平粗面岩類および葛尾火山 岩類の高い SrI 值の説明が可能であり, 葛尾カルデラの形 成時期は平粗面岩類の活動時期と少なくとも同じか, それ 以降であり, 葛尾火山岩類を覆う大峯玄武岩類の活動より 前であったと考えられる。

(6) 鮮新世以降に活動したアルカリ玄武岩類, 特に大峯 玄武岩類中には大量のマントル由来の捕獲岩類が存在す る。青木 (1977) は, それらを運んできたアルカリ玄武岩マ グマが地殼上部のマグマ溜りで止まった場合, 比重の大き い超苦鉄質・苦鉄質捕獲岩は急速に取去られるとし, アル カリ玄武岩マグマは比較的短時間に噴出したと述べてい る。このような急速なマグマ上昇の理由として, 山崎 (1998) は, 引張応力場への変化に伴う傾動地塊運動の進行 による地殼内での断裂系の発達を考えている。このとき， 島後北東部では，アルカリ玄武岩類との成因関係が認めら れるトカゲ岩粗面岩の噴出が起きた (Fig. 15f)。

\section{VI. まとめ}

本論では，隠岐島後で末期中新世に活動した隠岐アルカ リ火山岩類の全分布域にわたる詳細な地質図を作成して, 「隠岐アルカリ火山岩類」を再定義した。さらに, 本火山岩 類の構成岩とそれらの層序関係を明らかにし, 島後の末期 中新世〜鮮新世における火成活動史を論じた。

(1) 隠岐アルカリ火山岩類は, ショショナイト, 粗面安 山岩, 2 種類の粗面岩類 (下部層 上部層: 粗面岩類 1 ; 上 部層: 粗面岩類 2), 6 種類の流紋岩 (下部層: 五箇流紋岩 類, 都万流紋岩類, 西郷流紋岩類; 中部層: 久見流紋岩類, 加茂流紋岩類; 上部層: 白島流紋岩類) からなり, 従来の報 
告に比べてはるかに多様な火山岩類が認められた。

(2) 粗面安山岩の存在が明らかとなり,このことによっ て従来隠岐アルカリ火山岩類の重要な特徵であるとされて きた「ショショナイトと粗面岩類の間の組成ギャップ」は 存在しないことが明らかとなった。

(3) 岩石記載, 微量元素含有量に違いがある各流紋岩類 の $\mathrm{Qz}^{-} \mathrm{Ab}-\mathrm{Or} ノ ル ム$ 組成 $(\mathrm{An}<3.5 \mathrm{wt} \%)$ は，隠岐アルカ リ火山岩類の全分布域において, 下部層流紋岩類, 中部層 流紋岩類ごとに異なる領域に集中し，それらの間に中間的 な組成を示す流紋岩は存在しない。このことは，小林・沢 田 (1998) が述べているように, 下部層流紋岩類が下部地 殼物質, 中部層流紋岩類が中部地殼物質の部分融解により 形成されたことを示唆している。

（4）隠岐アルカリ火山岩類は，下部〜中部地殼物質の部 分融解を引き起こした塩基性マグマの上昇・貫入に伴う ドーム状隆起の形成に関連した環状割れ目に沿った，複数 の火道群から供給された。

(5) 多様な構成岩からなる隠岐アルカリ火山岩類の噴 出後, 平粗面岩類に属する粗面岩マグマがそれらに貫入し た。それと同時期またはその後, 葛尾火山岩類が葛尾山力 ルデラを形成しながら噴出した。これらの活動をもつて珪 長質アルカリ岩の活動は終焉し, 傾動運動で特徴づけられ る鮮新世に入ると, アルカリ玄武岩を主とする活動となっ た。

謝 辞 コスモ建設コンサルタント株式会社の村上 久氏には地質調査にあたり御指導をいただいた。東北大学 の蟹澤聰史名誉教授, 石川賢一博士, 島根大学の飯泉滋教 授, 小室裕明教授, 木村純一助教授には本研究を進めるに あたり終始御助力いただいた。バリー・ロザー博士には英 文要旨を書くにあたり御指導をいただいた。隠岐島後の 町・村役場の方々には調査地域の地形図を頂いた。島根大 学付属臨海実験所の方々には滞在中に大変御世話していた だいた。また, 藤林紀枝氏, 永尾隆志氏には, 初期原稿の 不備の指摘と懇切丁寧な御助言をいただいた。以上の方々 に深く感謝します。

\section{引用文献}

相澤幸治, 吉田武義 (2000): ラコリス状マグマ溜り. 月刊地 球, 22, 387-392.

青木謙一郎 (1977): 隠岐島後中村の超苦鉄質・苦鉄質捕獲 岩. 岩鉱, 72, 75-84.

藤巻宏和, 徐 紅, 青木謙一郎 (1989): 島根県隠岐, 島後 のミュジアライトの K- $\mathrm{Ar}$ 年代. 岩鉱, 84, 335-338.

藤巻宏和, 徐紅, 青木謙一郎 (1991): 島根県隠岐, 島後 火山岩類のストロンチウム同位体組成の時間的変化. 岩鉱, 86, 16-26.

牛来正夫 (1940): 北満州五大連池火山産アルカリ玄武岩類 の成因に関する 1 考察 (其の 1). 地質雑, 84, 335-338.

Hoshino, M. (1979): Two-pyroxene Amphibolites in Dogo, Oki Islands, Shimane-ken, Japan. J. Japan. Assoc. Min. Petr. Econ. Geol., 74, 87-99.

石田英明 (1985): 隠岐島後西部におけるアルカリ火山岩類
の層序. 島根大学地質学研究報告, 4, 69-79.

Johannes, W. and Holtz, F. (1990): Formation and composition of $\mathrm{H}_{2} \mathrm{O}$-undersaturated granite melts. In High-temperature metamorphism and crustal anatexis (Ashworth, J.R. and Brown, M. Eds). Unwin Hyman, London, 87104.

Kaneoka, I., Takahashi, E. and Zashu, S. (1977): K-Ar dating of alkali basalts from the Oki-Dogo island. $J$. Geol. Soc. Japan., 83, 187-189.

Kimura, J. and Yamada, Y. (1996): Evaluation of major and trace elements XRF analyses using a flux to sample ratio of two to one glass beads. J. Min. Petr. Econ. Geol., 91, $62-72$.

小林英夫, 松本征夫, 星野光雄 (1980): 隠岐島後. 日本地質 学会第 87 年総会年会, 見学旅行案内書, 1-39.

小林伸治, 沢田順弘 (1998): 隠岐島後における末期中新世隠 岐アルカリ火山岩類の成因. 岩鉱，93，162-181.

小林伸治, 沢田順弘, 吉田武義, 飯泉 滋, 木村純一 (2000): 隠岐島後における末期中新世アルカリ火山岩類の成 因. 日本地質学会第 107 年学術大会講演要旨， 327 .

Le Bas, M.J., Lemaitre, R.W., Streckeisen, A. and Zanettin, B. (1986): A chemical classification of volcanic rocks based on the total alkali-silica diagram. J. Petrol., 27, 745750.

松本征夫 (1984): 島根県隠岐群島 “島後カルデラ”について の考察. 島根大学地質学研究報告, 3, 111-119.

沢田順弘, 中村唯史, 楳田禎久, Sun Yoon, 徳岡隆夫 (1997): 島根県大田市の掘削コアから発見された欝陵島の完新 世初期火山活動由来の漂着軽石. 第四紀研究, 36, 1-16.

沢田順弘，當銘あかね，小林伸治，小室裕明，北川博也，村 上 久 (1999): 隠岐島後, 末期中新世葛尾火山岩類中 の火道とフィーダー岩脈。地質雑，105, VII-VIII.

沢田順弘, 高須 晃 (1999): 島根県益田市の部分融解ガラス を含む含藍晶石片麻岩質捕獲岩. 地質学論集, 53, 35-46.

沢田順弘, 角替敏昭, 山崎博史, 小林伸治, 村上 久 (2000): 隠岐島後. 日本地質学会第 2000 年学術大会, 見学旅行 案内書, B-8 斑, 115-134.

冨田達 (1927-1932): 隠岐島後の地質学的並びに岩石学的 研究. 地質雑, 34, 321-338, 423-460, 35, 463-491, 519537, 571-600, 36, 189-205, 303-337, 37, 131-156, 521546, 38, 155-173, 203-222, 413-431, 461-479, 545-564, 609-628, 39, 149-178, 197-218, 501-523, 609-640, 675691.

Uchimizu, M. (1966): Geology and petrology of alkali rocks from Dogo, Oki Islands. J. Fac. Sci., Univ. Tokyo, Sec. II, 16, 85-159.

Uto, K., Takahashi, E., Nakamura, E. and Kaneoka, I. (1994): Geochronology of alkali volcanism in Oki-Dogo Island, Southwest Japan: Geochemical evolution of basalts related to the opening of the Japan Sea. Geochem. J., 28, 431-449.

徐 紅, 吉田武義, 青木謙一郎 (1987): 隠岐島後に産するア ルカリ火山岩類の地球科学的研究. 隠岐島後に産する アルカリ火山岩類の地球化学的研究. 東北大核理研研 究報告, 20, 179-201.

Xu, H. (1988): Petrology and geochemistry of the alkali rocks from Dogo, Oki Islands, Shimane Prefecture, Southwestern Japan. Sci. Rept., Tohoku Univ., Ser. III, 17, 1-106. 山上万次郎 (1895): 20 万分の 1 地質図幅隠岐および説明 書. 農務省地調, 1-31.

山崎博史 (1984): 隠岐島後の中新統. 島根大学地質学研究報 告, 3, 87-97.

山崎博史 (1998): 隠岐島後の後期新生代堆積一造講史と日 
本海南部に抢ける地形的・構造的起状起源. 広島大学学 校教育学部紀要, 第 II 部, 20, 85-153.
Yoshida, T. (1984): Tertiary Ishizuchi Cauldron, Southwestern Japan Arc. J. Geophys. Res., 89, 8502-8510. 